\title{
The kyanite quartzite of Bosland (Suriname): evidence for a Precambrian metamorphosed alteration system
}

\section{Ginny Bijnaar ${ }^{1,2, *}$, Manfred J. van Bergen ${ }^{3} \&$ Theo E. Wong ${ }^{1}$}

\author{
1 Department of Geology and Mining, Anton de Kom University of Suriname, Paramaribo, Suriname \\ 2 Present address: Leysweg 86, Paramaribo, Suriname \\ 3 Department of Earth Sciences, Utrecht University, Utrecht, The Netherlands \\ * Corresponding author. Email: ginny.bijnaar@gmail.com
}

Manuscript received: 20 December 2015, accepted: 9 September 2016

\section{Abstract}

This article investigates the origin of a rare occurrence of kyanite quartzites in the Palaeoproterozoic greenstone belt of Suriname. The rocks form elongated hills in the Bosland area, Brokopondo district, where they are associated with meta-sedimentary, meta-volcanic and granitic lithologies. Their mineral content and unusual Si- and Al-rich chemical composition are inferred to be the result of advanced argillic alteration of felsic volcanic tuffs and a later overprint by regional metamorphism up to lower amphibolite facies during the Trans-Amazonian orogeny. Structurally, the Bosland area seems centred within a contractional strike-slip duplex of a major dextral fault system. The alteration was probably associated with a high-sulphidation environment and involved significant to almost complete removal of alkali and alkaline earth elements. Pseudosection modelling and textures suggest that the precipitation-temperature $(P-T)$ history of the kyanite quartzites started with shallow $(<2$ kbar) hydrothermal alteration of the acidic tuffaceous volcanics, possibly in the andalusite stability field $\left(T>350^{\circ} \mathrm{C}\right)$, and ended in peak metamorphic conditions in the kyanite-staurolite stability field $\left(P>4 \mathrm{kbar}\right.$ and $\left.T=500-650^{\circ} \mathrm{C}\right)$. Alteration events that preceded the peak of Trans-Amazonian metamorphism may be more common in the rock record of Suriname's greenstone belt, which lends support to the hypothesis that gold mineralisations in the region can be pre-orogenic.

Keywords: hydrothermal alteration, kyanite, Proterozoic, quartzites, Suriname

\section{Introduction}

Because of their unusual chemical composition, kyanite quartzites are uncommon in metamorphic belts world-wide. In Scandinavia, kyanite quartzites occur in a volcano-sedimentary sequence of Palaeoproterozoic age that underwent upper greenschist- to amphibolite-facies metamorphism and was intruded by granitic plutons (Larsson, 2001; Müller et al., 2007). In the Piedmont province of Virginia (USA), they are part of a metamorphosed Palaeozoic volcano-sedimentary belt (0wens \& Pasek, 2007). Palaeoproterozoic quartz-kyanite schist pods occur within a mica schist layer as part of an assemblage of metamorphosed rhyolite tuff and flows, micaceous quartzite and metaconglomerate (Simmons et al., 2011). Kyanite-quartzite deposits are potentially of economic interest (1) because kyanite can be commercially exploited (e.g. Owens \& Pasek, 2007), (2) as prospective resources of high-purity quartz (Müller et al.,
2007) and (3) because of their association with gold mineralisation (Hallberg, 1994; Larsson, 2001; Oliveira et al., 2016).

The Bosland area in the Brokopondo district of Suriname hosts a rare occurrence of kyanite quartzites in Palaeoproterozoic supracrustal rocks of the Guiana Shield. Following their discovery in the early 1900s, these rocks have been explored for their potential as a resource for kyanite and quartzite aggregates (De Haan, 1953; Ter Meulen, 1953; Salzgitter, 1966). This article documents field aspects, petrological and geochemical characteristics, and presents evidence for an origin as metamorphic equivalent of highly altered felsic volcanics.

\section{Geological setting}

The Bosland area, located approximately $83 \mathrm{~km}$ southeast of Suriname's capital Paramaribo, is part of the Marowijne 
Greenstone Belt, which belongs to the large Palaeoproterozoic greenstone belt that extends between Venezuela and northeastern Brazil across the Guiana Shield. The Marowijne Greenstone Belt comprises the volcanic-sedimentary Paramaka Formation (mafic and intermediate metavolcanics, metacherts and phyllites), the sedimentary Armina Formation (metagreywackes and phyllites) and the sedimentary Rosebel Formation (metasandstones and conglomerates) (de Vletter, 1984). These rocks are associated with tonalite-trondhjemite-granodiorite (TTG) and younger granitic intrusives (Bosma et al., 1977; De Vletter, 1984). All supracrustal rocks are metamorphosed to greenschist - lower amphibolite facies and are strongly folded. Deformation and metamorphism occurred during an early phase of the Trans-Amazonian Orogeny between 2.18 and $2.09 \mathrm{Ga}$, presumably when the Amazonian and West African cratons converged and collided (Delor et al., 2003; Daoust et al., 2011; Kroonenberg et al., 2016).

The Bosland kyanite quartzites were first discovered by $\mathrm{Du}$ Bois (1901). They are exposed in three north-south-trending hills at $140 \mathrm{~m}$ a.s.l., which stand out over a length of $1800 \mathrm{~m}$ and a width of $c .300 \mathrm{~m}$, showing a steep western flank. The Dubois Hill in the centre of the array is the subject of this study. According to the geological map of Bosma et al. (1977), the kyanite quartzites are part of a schist-quartzite unit of the Paramaka Formation, which is spatially associated with phyllite, metachert and meta-andesite. To the north of the hills, a biotite granite with an envelope of staurolite-garnet schist is exposed.

Early research focused on the area as a potential target for mining kyanite and/or quartzite aggregates (De Haan, 1953; Ter Meulen, 1953; Salzgitter, 1966). Kartoredjo (1983) compiled a comprehensive list of available reports on the deposit. According to these surface surveys, kyanite can be followed in a $c .3 \mathrm{~km}$ long and $c .100 \mathrm{~m}$ wide $\mathrm{N}$-S-directed zone (Salzgitter, 1966; Kartoredjo, 1983), where it occurs as mono-mineralic rock lenses, as a constituent of quartzite and in veins (Fig. 1). The Geological and Mining Service of Suriname (GMD) collected four drill cores from the Dubois Hill in 1986 but no results or interpretations were published.

Ter Meulen (1953) distinguished four different types of quartzite: (1) kyanite-pyrite-sericite quartz, (2) kyanitechloritoid quartzite with andalusite and staurolite, (3) staurolite-kyanite quartzite and (4) kyanite-sericite quartzite with pyrite. Recent geological mapping of the Dubois Hill documented the distribution of these four types of quartzite and an associated schist unit; Fig. 2). The approximately N-S-trending rock sequence dips $c .50^{\circ}$ westwards and is dissected by three approximately E-W-striking faults.

\section{Research strategy and methods}

Field surveys, focused on the Dubois Hill, benefited from good outcrops on its top, resulting from past excavations in search

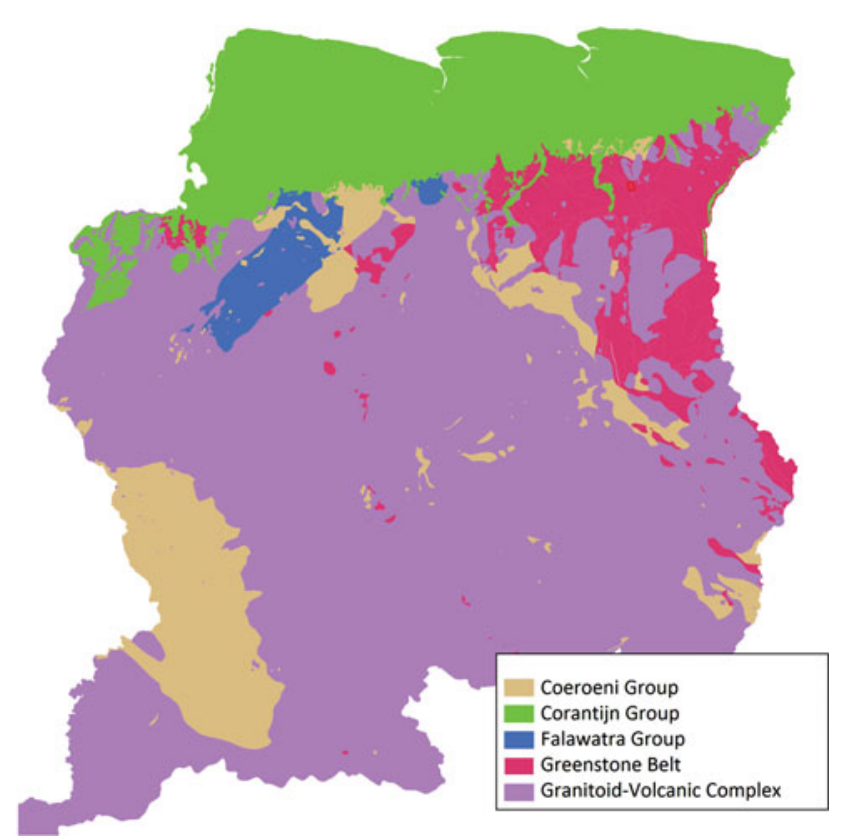

Fig. 1. Main geological units of Suriname after Bosma et al. (1977), with omission of the Roraima Formation and dolerite dykes. The yellow star shows the location of Bosland.

of fresh rock for exploitation as aggregates. Nevertheless, mapping and collection of a complete set of representative samples proved difficult due to extensive tropical weathering and dense vegetation. Relatively fresh rock samples were obtained with a handheld diamond drill. Thin sections were cut in slices parallel and perpendicular to the foliation for microscopic investigation. Four rock samples were analysed for bulk chemical composition at ALS Peru Laboratory (Lima, Peru). Major elements were determined by X-ray fluorescence (XRF) on lithium borate glass beads, and trace elements by inductively coupled plasma mass spectrometry (ICP-MS) following lithium borate fusion and acid digestion. Sulphur and copper concentrations were determined by interactively coupled plasma emission spectroscopy (ICP$\mathrm{AES}$ ), following aqua-regia digestion, at Filab (Paramaribo). Loss on ignition (LOI) was determined at $1000^{\circ} \mathrm{C}$. Pseudosections, based on Gibbs free-energy minimisation, were constructed using the Perplex software suite (version 6.7.1). The model system KFMASH $\left(\mathrm{K}_{2} \mathrm{O}-\mathrm{Fe} 0-\mathrm{MgO}-\mathrm{Al}_{2} \mathrm{O}_{3}-\mathrm{SiO}_{2}-\mathrm{H}_{2} \mathrm{O}\right)$ was selected based on abundances of the major elements and the minerals present in the rocks.

\section{Field appearance and petrography}

The investigated summit of the Dubois Hill consists of a sequence of four rock units (A-D), trending $N 350^{\circ} \mathrm{E}$ and dipping $50^{\circ} \mathrm{W}$ (Fig. 3). The two outermost units appeared as most resistant and responsible for the morphology of the hill. The boundaries between the rock units are stratigraphic in nature, showing gradual rather than sharp transitions. 

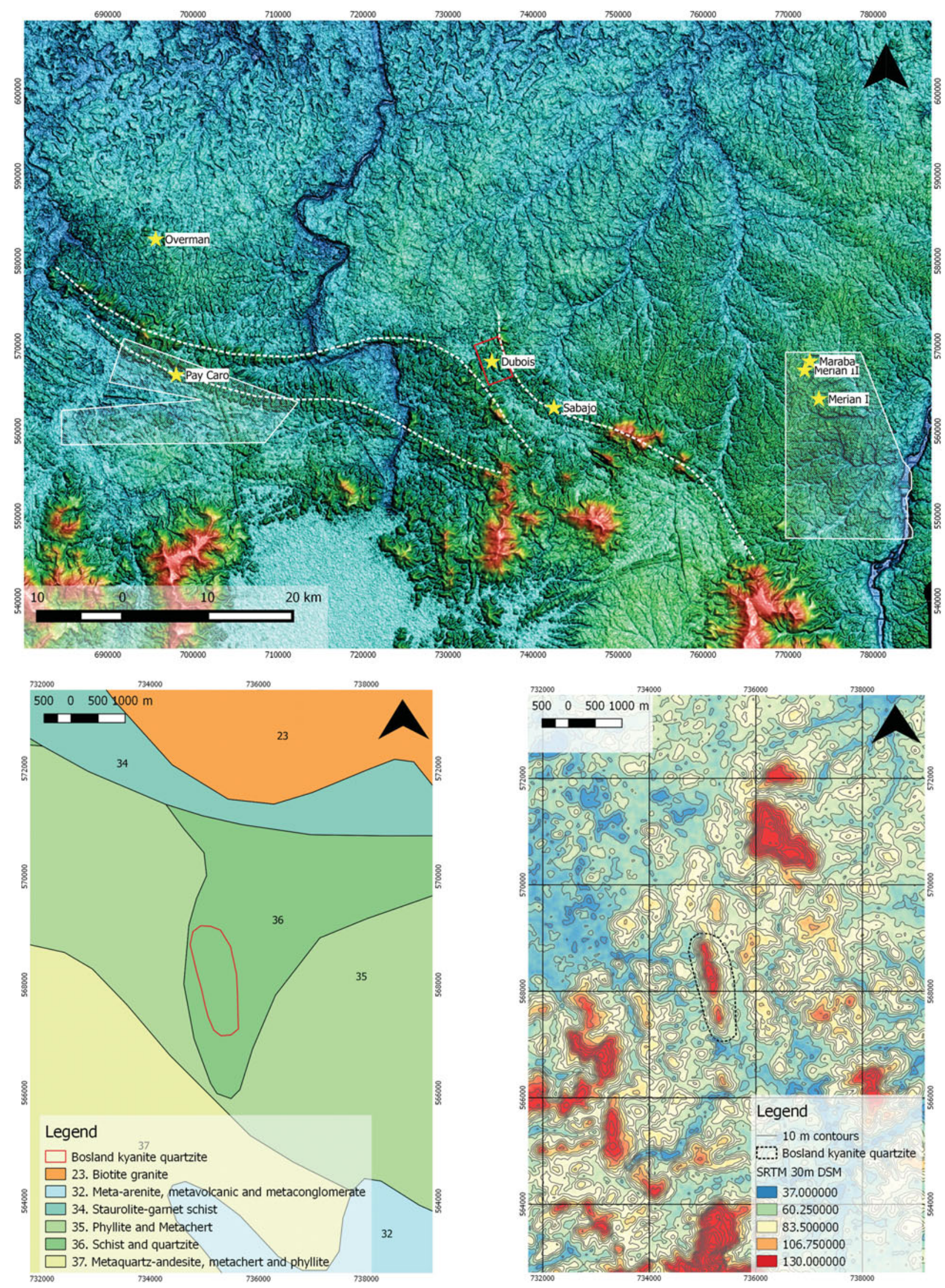

Fig. 2. (A) Interpretation of regional structures around the Dubois Hill in relation to two large-scale mining concessions. (B) Simplified local geology of the study area (Bosma et al., 1977). (C) Topography of the kyanite quartzite and surrounding area (10 m contours on Shuttle Radar Topography Mission 1 (SRTM 1) arcsecond). 


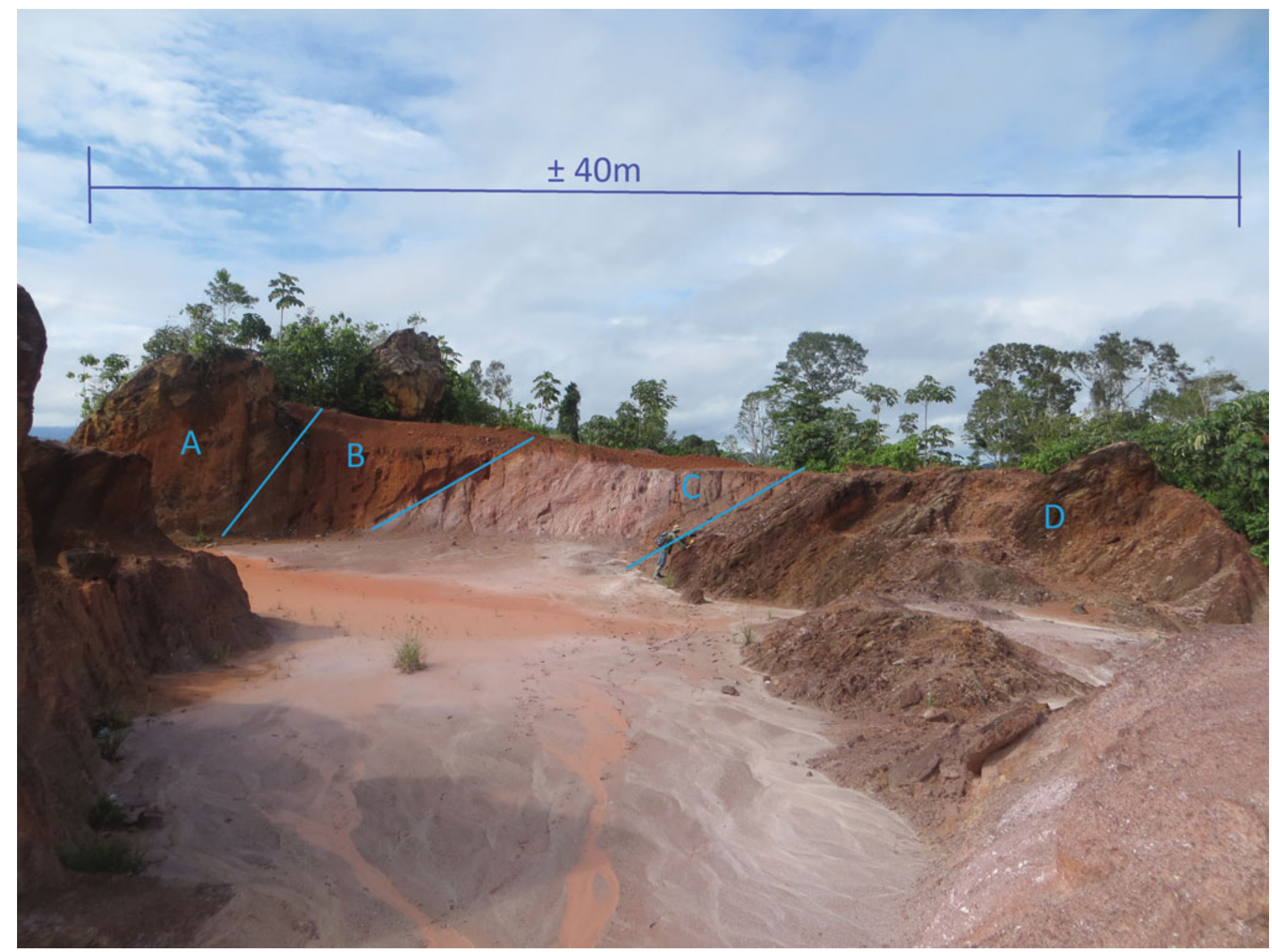

Fig. 3. Section view of the Dubois Hill, looking south.

In the field, kyanite occurs in foliation planes, in veins and as massive lenses within the quartzite units ( $A, B$ and $D)$. In foliation planes (3-5 mm thick), it has a preferred orientation and often appears as radial aggregates (Fig. 4A). Although veins (1-3 cm thick) mostly consist of quartz with occasionally visible kyanite, there are also a few small, irregularly shaped veins that only contain kyanite (Fig. 4C, D). Kyanite in quartz veins shows inward growth from the edges or no preferred orientation (Fig. 4C). Scattered boulders of massive kyanite were also encountered (Fig. 5A), and one up to $25 \mathrm{~cm}$ thick massive body of kyanite with an irregular lens shape was found in situ (Fig. 5B). In thin section, quartz grains displayed multiple size ranges, and many quartz and kyanite grains showed fracturing. Unlike the host rock assemblages, andalusite appeared to be absent. The quartz and quartz-kyanite veins at the Dubois Hill trend NE-SW and cross-cut the foliation (Fig. 5B). To the south of the Dubois Hill are artisanal gold workings near a vertical c. $15 \mathrm{~cm}$ thick shear vein with the same orientation as the other veins (Fig. 5C).

Unit A is a very hard, fine-grained grey quartzite with brown weathering spots. It forms the highest point of the outcrop.
Microscopic inspection of sample DB-A classifies the rock as chloritoid-kyanite-staurolite quartzite with rutile. Quartz forms tightly interlocking grains in the $0.05-0.2 \mathrm{~mm}$ size range, showing a granoblastic texture, undulatory extinction and subgrains. Abundant blue-green chloritoid is present as euhedral crystals, often in radially oriented clusters. Sub- to anhedral porphyroblasts of staurolite with its characteristic yellow colour have a poikilitic texture with quartz inclusions. The mineral is often closely associated with chloritoid and sparse chlorite. Kyanite is distinguishable by its strong relief, perfect cleavage on $\{100\}$ and sometimes also a good cleavage on $\{010\}$. Grains are mostly euhedral prisms, while others have borders with a jagged appearance. Contacts with chloritoid suggest a reaction relationship. There are few andalusite crystals, which mostly form large skeletons. Abundant dark-brown rutile is disseminated as small anhedral to subhedral crystals throughout the sample. Some crystals have radiation-damage halos.

Unit B has no well-defined boundary with Unit A, but colour and stronger weathering yield a distinct appearance. Microscopic inspection of a grab sample (DB-B), taken from one of a number of large Unit B boulders close to the outcrop, classifies 

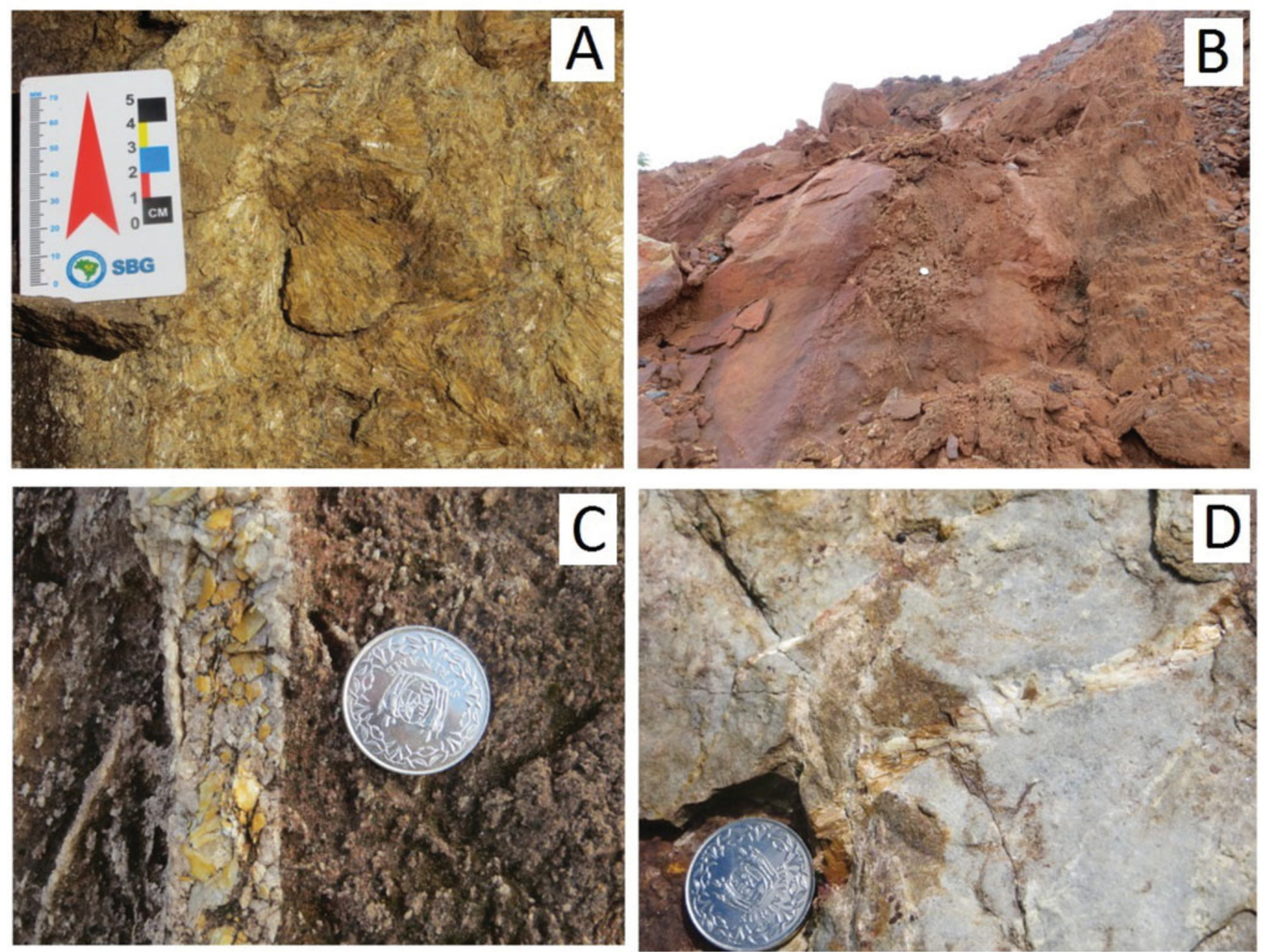

Fig. 4. (A) Radial kyanite crystals on a weathered foliation plane. (B) In situ massive kyanite lens. (C) Weathered quartz vein with randomly oriented kyanite. (D) Irregularly shaped kyanite vein.

the unit as a kyanite quartzite with rutile. The rock contains c.85\% quartz. Mineralogy, texture as well as interrelationships between staurolite, chloritoid and chlorite are quite similar to Unit A. Muscovite is present as small isolated flakes, except for larger crystals that occur in clusters, often surrounded by depletion halos. Dark brown rutile is again abundant. Sulphides are also common and appear as small cubic opaque grains showing blue patches. Some of the opaques are interpreted to be chalcopyrite, based on colour and significantly higher $\mathrm{Cu}$ concentration of the bulk sample (DB04, see below). Zircon (somewhat rounded) and apatite grains are other accessory minerals. Limonite alteration is locally visible around grain boundaries.

Unit $\mathrm{C}$ is a fine-grained, pinkish-tan schist with $>80 \%$ mica, much of which is weathered to clay. Kyanite was macroscopically observed in foliation planes. Weathering made the rock so friable that no hand specimen could be collected.

Unit D appears in the field as a bluish-grey quartzite with abundant fine-grained sulphides $(3 \%)$, which are disseminated throughout the rock. Kyanite could be identified with the naked eye on foliation planes. Sample DB-D1 represents a weathered quartzite with relics of sulphides, while DB-D2 was taken from a fresher part of the outcrop and contains sulphide crystals that are still intact. Microscopically the rock can be labelled as kyanite-pyrite quartzite with andalusite. Foliation is evident from the presence of quartz bands with alternating sizes. In general, andalusite forms large, anhedral porphyroblasts, some of which show lamellar or simple twinning. The crystals are speckled with inclusions of opaques or quartz. The andalusite crystals have jagged boundaries and are always in contact with or in proximity to kyanite (Fig. 6). The kyanite is subhedral to anhedral, but generally has more distinct edges than andalusite. Sparse muscovite flakes have also been found. The thin sections confirm the presence of abundant sulphide grains in different state of weathering. As in Unit B, pyrite is probably accompanied by chalcopyrite, based on colour differences and a relatively high $\mathrm{Cu}$ content of the bulk sample. Blue patches are interpreted as covellite. 

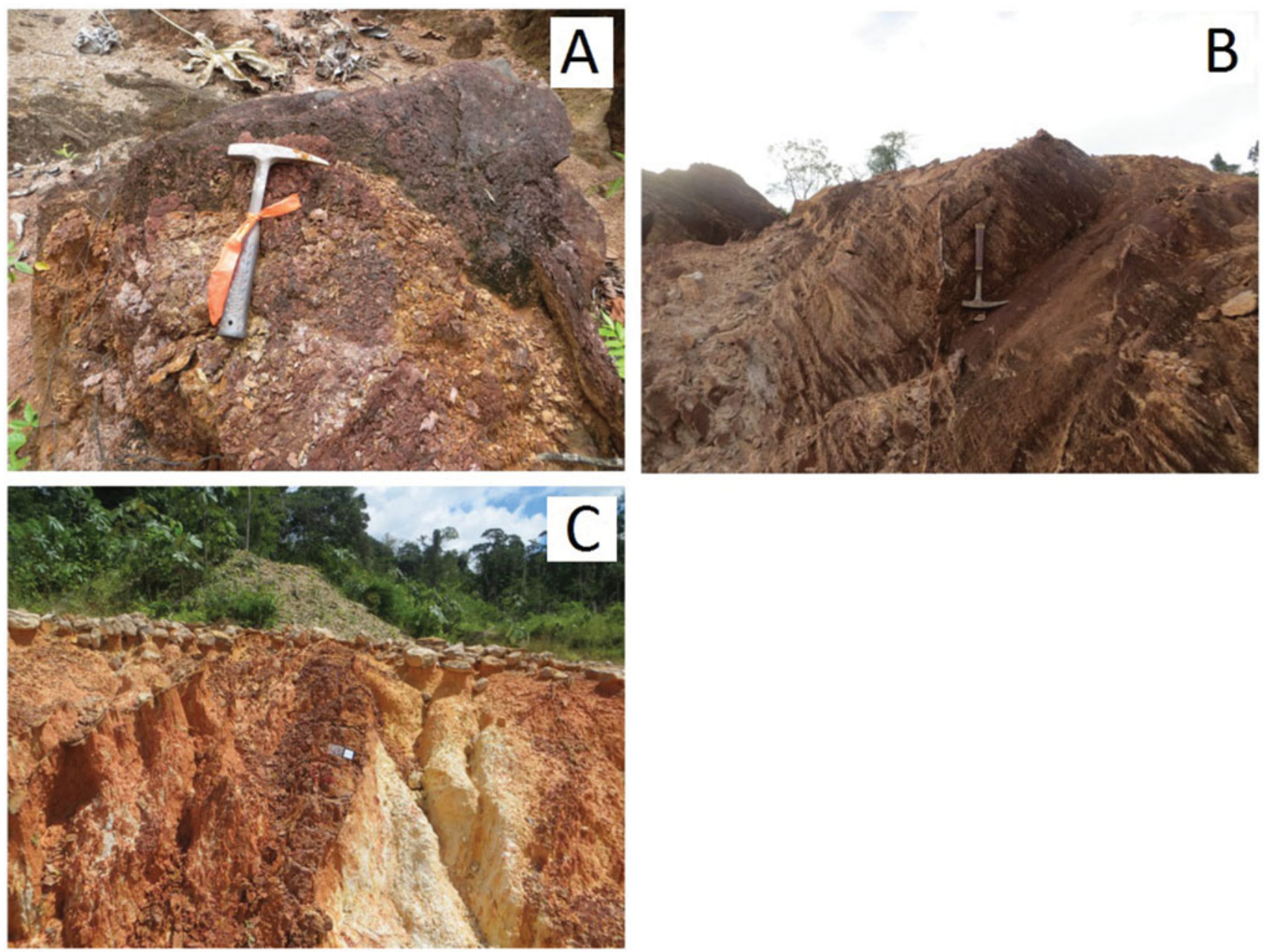

Fig. 5. (A) Boulder of massive kyanite in Unit A. (B) Quartz veins cross-cutting foliation in Unit A. (C) Shear vein in artisanal gold workings to the south of the Dubois Hill.

\section{Rock chemical compositions}

Major and trace element concentrations in the selected quartzite samples are reported in Table 1 . The analysed rocks have a restricted compositional range and consist primarily of $\mathrm{SiO}_{2}$ (72-78wt\%) and $\mathrm{Al}_{2} \mathrm{O}_{3}$ (15-21 wt\%). Variations in $\mathrm{Fe}_{2} \mathrm{O}_{3} \mathrm{~T}$ (expressing total iron) and $\mathrm{TiO}_{2}$ are larger than for the other oxides, with ranges between 3 and $6 \mathrm{wt} \%$, and between 0.80 and $1.20 \mathrm{wt} \%$, respectively. The rocks show a strong depletion in $\mathrm{CaO}, \mathrm{MgO}, \mathrm{Na}_{2} \mathrm{O}$ and $\mathrm{K}_{2} \mathrm{O}$, with values $<0.20 \mathrm{wt} \%$. Concentrations are also low for the trace elements $\mathrm{Sr}, \mathrm{Rb}, \mathrm{Ba}$ and $\mathrm{Cs}$. Sulphur and copper concentrations are relatively high in sample DB04 (2.15 wt\% and $124 \mathrm{ppm}$, respectively), which is in agreement with the abundance of pyrite and Cu-bearing sulphide. The concentrations of these elements are significantly lower in the more weathered sample of the same unit (DB01). Chondritenormalised rare earth element (REE) patterns show light rare earth element (LREE) enrichment and a flat distribution from Tb to Lu (Fig. 7).

\section{Discussion}

The kyanite quartzites at Bosland have a peculiar composition of predominantly $\mathrm{SiO}_{2}$ and $\mathrm{Al}_{2} \mathrm{O}_{3}$, with extremely low values for alkalis and alkali earths. This composition deviates from more common $\mathrm{Al}_{2} \mathrm{SiO}_{5}$-mineral-bearing rocks, which are usually metapelites (e.g. Sepahi et al., 2004; Beitter \& Wagner, 2008), and is atypical for volcanic, sedimentary or metamorphic rocks in general. Although no chemical analysis of the Unit C schist was done, the high white mica content dictates a higher $\mathrm{K}$ content than the quartzites. Chemical alteration indices applied to the rocks confirm the unusual composition. Values for the Chemical Index of Alteration (CIA), the Weathering Index of Parker (WIP) (Price \& Velbel, 2003) and the Advanced Argillic Alteration Index (AAAI) (Doyle et al., 2004) are 99-100, 0-1 and 94-98, respectively, implying a maximum degree of alteration/weathering. Major, minor and trace element concentrations normalised to values for Upper Continental Crust (UCC; Taylor \& McLennan, 1985), further illustrate the exceptional 

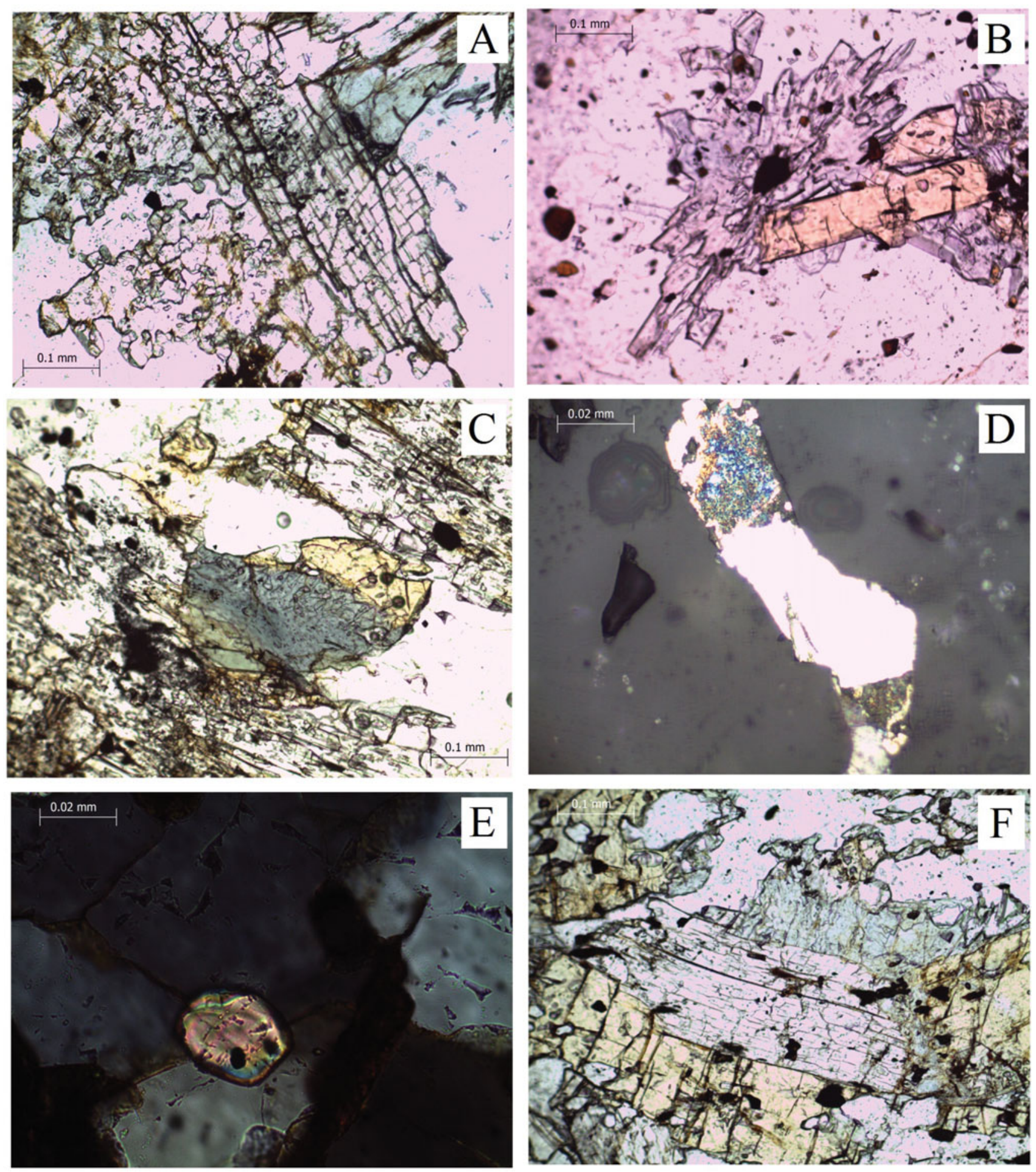

Fig. 6. Selected microphotographs of the kyanite quartzites. (A) Skeletal andalusite (right) next to subhedral kyanite. (B) Radial chloritoid with subhedral yellow staurolite and abundant dark brown rutile. (C) Peculiar grain consisting of chlorite, chloritoid and staurolite in between high-relief kyanite. (D) Opaque grain in reflected light showing blue covellite (?) patches. (E) Zircon. (F) Colourless kyanite flanked by blue green chloritoid and yellow staurolite. 
Table 1. XRF results for major and some minor oxides in wt\%, ICP-MS trace element concentrations in ppm and ICP-AES results for $S$ and $\mathrm{Cu}$.

\begin{tabular}{|c|c|c|c|c|c|}
\hline 0xide/element & Unit & $\begin{array}{l}\text { Unit D } \\
\text { DB01 }\end{array}$ & $\begin{array}{l}\text { Unit A } \\
\text { DB02 }\end{array}$ & $\begin{array}{l}\text { Unit D } \\
\text { DB04 }\end{array}$ & $\begin{array}{l}\text { Unit B } \\
\text { DB06 }\end{array}$ \\
\hline $\mathrm{SiO}_{2}$ & $\%$ & 71.63 & 74.69 & 74.36 & 78.31 \\
\hline $\mathrm{Al}_{2} \mathrm{O}_{3}$ & $\%$ & 21.01 & 19.25 & 19.04 & 14.79 \\
\hline $\mathrm{Fe}_{2} \mathrm{O}_{3}$ & $\%$ & 5.8 & 3.45 & 3.93 & 5.57 \\
\hline $\mathrm{CaO}$ & $\%$ & 0.02 & 0.07 & 0.02 & 0.21 \\
\hline $\mathrm{MgO}$ & $\%$ & 0.07 & 0.21 & 0.08 & 0.22 \\
\hline $\mathrm{Na}_{2} \mathrm{O}$ & $\%$ & 0.06 & 0.04 & 0.05 & 0.09 \\
\hline $\mathrm{K}_{2} \mathrm{O}$ & $\%$ & 0.14 & 0.03 & 0.07 & 0.13 \\
\hline $\mathrm{TiO}_{2}$ & $\%$ & 0.83 & 1.21 & 0.78 & 0.79 \\
\hline $\mathrm{Mn} 0$ & $\%$ & 0.01 & 0.03 & 0.02 & 0.01 \\
\hline $\mathrm{P}_{2} \mathrm{O}_{5}$ & $\%$ & 0.133 & 0.115 & 0.095 & 0.197 \\
\hline LOI & $\%$ & 0.76 & 0.61 & 2.06 & 0.39 \\
\hline Total & $\%$ & 100.46 & 99.71 & 100.51 & 100.71 \\
\hline $\mathrm{Ba}$ & $\mathrm{ppm}$ & 144 & 24.8 & 54.1 & 368 \\
\hline $\mathrm{Ce}$ & $\mathrm{ppm}$ & 78 & 102 & 113 & 68.6 \\
\hline Cs & $\mathrm{ppm}$ & 0.15 & 0.08 & 0.14 & 0.39 \\
\hline Dy & $\mathrm{ppm}$ & 5.76 & 4.27 & 4.21 & 3.38 \\
\hline Er & $\mathrm{ppm}$ & 3.53 & 2.38 & 2.16 & 2.02 \\
\hline $\mathrm{Eu}$ & $\mathrm{ppm}$ & 1.23 & 1.93 & 1.46 & 1.23 \\
\hline $\mathrm{Ga}$ & $\mathrm{ppm}$ & 32.2 & 27.3 & 28.7 & 25.2 \\
\hline $\mathrm{Gd}$ & $\mathrm{ppm}$ & 5.01 & 5.42 & 5.18 & 3.77 \\
\hline $\mathrm{Hf}$ & $\mathrm{ppm}$ & 9.4 & 7.1 & 9.2 & 5.5 \\
\hline Ho & $\mathrm{ppm}$ & 1.23 & 0.89 & 0.89 & 0.7 \\
\hline $\mathrm{La}$ & $\mathrm{ppm}$ & 43.4 & 53.5 & 59.5 & 34.7 \\
\hline $\mathrm{Lu}$ & $\mathrm{ppm}$ & 0.52 & 0.38 & 0.36 & 0.34 \\
\hline $\mathrm{Nb}$ & $\mathrm{ppm}$ & 29.9 & 42.2 & 31.1 & 22.2 \\
\hline $\mathrm{Nd}$ & $\mathrm{ppm}$ & 26.6 & 40.6 & 38.3 & 26.6 \\
\hline $\operatorname{Pr}$ & $\mathrm{ppm}$ & 7.92 & 11.15 & 11.6 & 7.6 \\
\hline $\mathrm{Rb}$ & $\mathrm{ppm}$ & 3 & 1.2 & 2.9 & 5.6 \\
\hline $\mathrm{Sm}$ & $\mathrm{ppm}$ & 4.35 & 7.57 & 6.09 & 4.98 \\
\hline $\mathrm{Sn}$ & $\mathrm{ppm}$ & 3 & 2 & 3 & 2 \\
\hline $\mathrm{Sr}$ & $\mathrm{ppm}$ & 29.3 & 23.1 & 23.5 & 9 \\
\hline $\mathrm{Ta}$ & $\mathrm{ppm}$ & 2.9 & 2.4 & 2.1 & 1.5 \\
\hline $\mathrm{Tb}$ & $\mathrm{ppm}$ & 0.92 & 0.85 & 0.68 & 0.58 \\
\hline Th & $\mathrm{ppm}$ & 8.61 & 7.46 & 10.2 & 5.93 \\
\hline $\mathrm{Tm}$ & $\mathrm{ppm}$ & 0.57 & 0.35 & 0.4 & 0.34 \\
\hline $\mathrm{U}$ & $\mathrm{ppm}$ & 3.19 & 0.87 & 3.71 & 1.35 \\
\hline V & $\mathrm{ppm}$ & 52 & 57 & 35 & 45 \\
\hline$Y$ & $\mathrm{ppm}$ & 36.1 & 23.8 & 24.6 & 20.5 \\
\hline $\mathrm{Yb}$ & $\mathrm{ppm}$ & 3.58 & 2.38 & 2.31 & 2.05 \\
\hline $\mathrm{Zr}$ & ppm & 467 & 325 & 448 & 246 \\
\hline S & $\%$ & 0.051 & 0.016 & 2.153 & $<0.01$ \\
\hline $\mathrm{Cu}$ & ppm & 12 & 4 & 124 & 4 \\
\hline
\end{tabular}

Normalised to chondrite values

(Sun \& McDonough 1989)

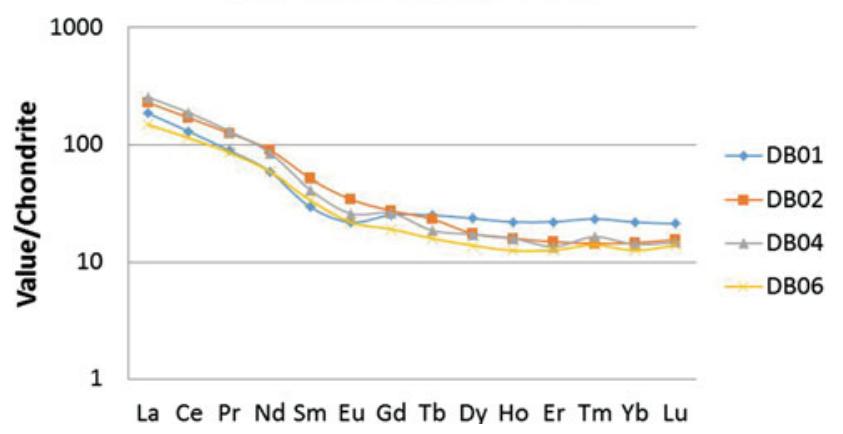

Fig. 7. Chondrite (Sun \& McDonough, 1989) normalised REE patterns for kyanite quartzites from the Dubois Hill.

composition of the kyanite quartzites, in particular their strong depletion in alkalis and alkali earth elements (Fig. 8). The following discussion will address the cause of the unusual composition, the possible nature of the protolith, the time when the composition was acquired relative to the metamorphic event and the conditions of metamorphism.

\section{Origin of the peculiar bulk composition: fluid-rock interaction}

The unusual chemical composition of the kyanite quartzites at Bosland points to some form of fluid interaction in the premetamorphic history that produced the $\mathrm{SiO}_{2}$-rich rock with moderately high $\mathrm{Al}_{2} \mathrm{O}_{3}$ contents and very low concentrations of alkali metals and alkaline earths. Supergene weathering and hydrothermal alteration are two processes to be considered.

Option 1: Surface weathering Surface weathering similar to laterisation or bauxitisation is a mechanism capable of creating the chemical composition of the kyanite quartzites by leaching of an igneous or sedimentary protolith with appropriate composition. In a standard weathering profile of lateritic bauxite, the bauxite of the top part is usually underlain by a mottled clay zone that, in turn, covers a saprock-saprolite which ultimately passes into fresh rock. In view of the high $\mathrm{SiO}_{2}$ content of the kyanite quartzites and the depletion in fluid-mobile elements, the bulk composition would correspond best with an interval between the clay zone and the saprock-saprolite, which often contains kaolinite. A study of weathering profiles on Palaeoproterozoic low-grade metamorphic volcanic and sedimentary rocks in the Omai gold mine, Guyana, (Voicu \& Bardoux, 2002) illustrates this. Here, $\mathrm{Na}_{2} \mathrm{O}, \mathrm{CaO}$ and $\mathrm{MgO}$ were strongly to completely leached in the saprolite, whereas $\mathrm{SiO}_{2}$ contents were mostly unaffected, $\mathrm{Al}_{2} \mathrm{O}_{3}$ showed minor relative enrichment due to its immobility, and the behaviour of $\mathrm{K}_{2} \mathrm{O}$ depended on the type of precursor rock.

The metamorphic texture and mineral assemblage of the kyanite quartzites rule out that any weathering-induced 


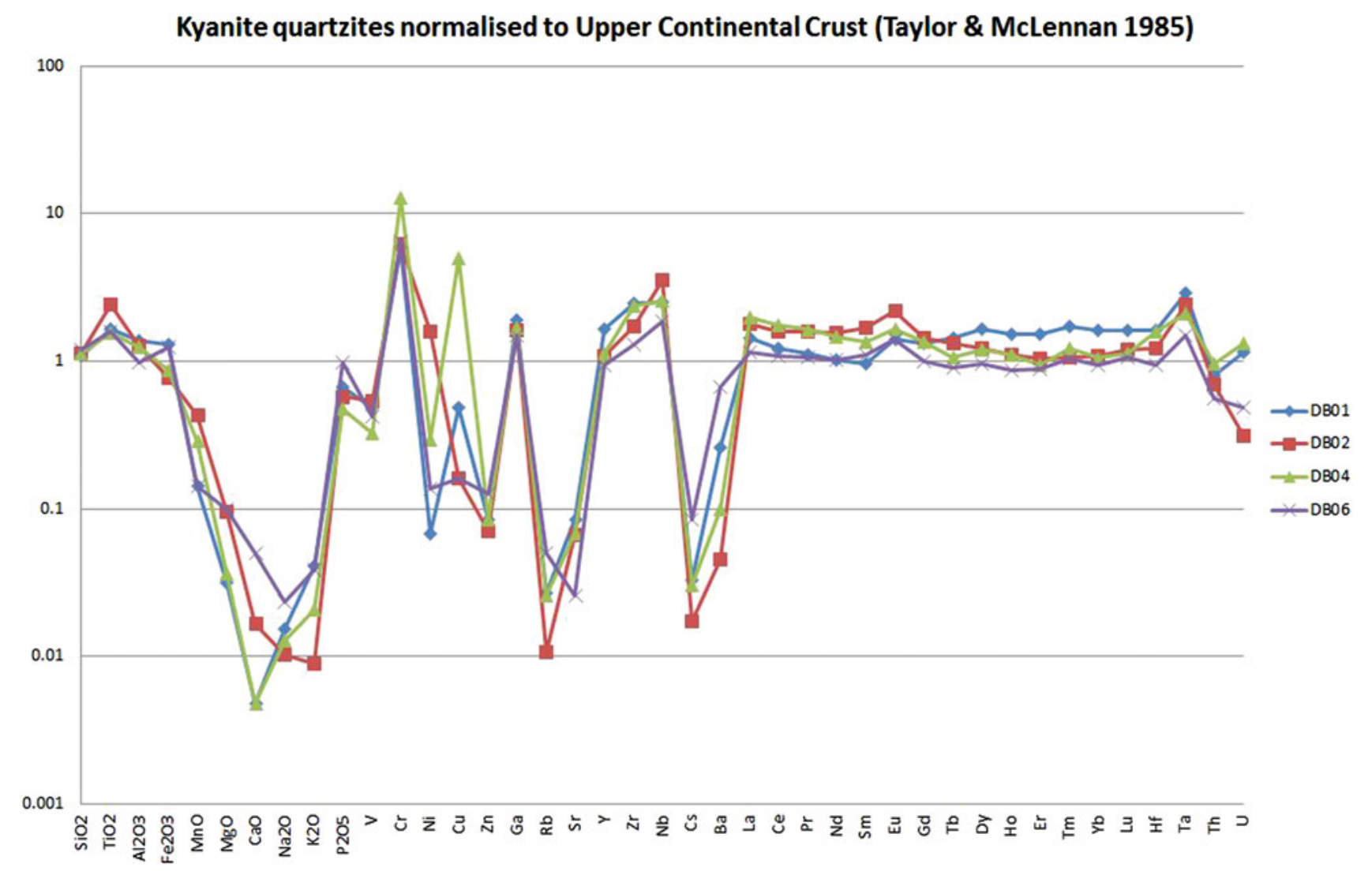

Fig. 8. Major, minor and trace element concentrations of the kyanite quartzite normalised to the Upper Continental Crust (Taylor \& McLennan, 1985).

leaching was associated with one of the recent (Late Cretaceous and predominantly Tertiary) events that produced widespread bauxites in Suriname (Bárdossy \& Aleva, 1990). If pedogenetic processes were responsible for the chemical composition of the pre-metamorphic Bosland precursor, surface weathering must have occurred in Precambrian times. Metamorphosed Precambrian palaeosols, including Al-rich varieties, have been recognised in cratonic settings around the world. For example, De Wall et al. (2012) described an ancient lateritic weathering profile along the Archaean-Proterozoic contact in the Aravalli craton, NW India, wherein original kaolinite in saprolite and a pallid zone had been transformed into kyanite during metamorphism. Golani (1989) interpreted quartz-sillimanite schist, hosting massive sillimanite-corundum deposits, as a metamorphosed palaeosol, representing an erosional unconformity in the Precambrian rocks of the Meghalaya Plateau, India. Reimer (1986) argued that many Al-rich rocks in the early Precambrian of the Kaapvaal Craton are indicators of palaeosols. Bol et al. (1989) attributed Al- and Fe enrichments in granulite-facies metabasites from the Proterozoic shield of Rogaland, Norway, to pre-metamorphic lateritisation.

The package of quartzites and schist at Dubois could represent a fining-upwards sequence of erosional products from such weathering zones. However, the very limited occurrence of the kyanite quartzite or other $\mathrm{Al}_{2} \mathrm{SiO}_{5}$-bearing rocks and the presence of pervasive pyrite are evidence against weathering being the main cause of the current chemical composition. This does not rule out that the original rocks were in fact such sediments that underwent hydrothermal alteration as discussed in the next paragraph.

Option 2: Advanced argillic alteration An alternative option for a pre-metamorphic origin of the $\mathrm{SiO}_{2}-\mathrm{Al}_{2} \mathrm{O}_{3}$ prevalence and depletion of alkali metals and alkaline earths of the rocks is that this composition was produced as a result of advanced argillic (high-sulphidation) alteration. The origin of various Al-rich, kyanite-bearing rocks has been attributed to metamorphism of hydrothermally altered rocks (Ririe, 1990; Hallberg, 1994; Larsson, 2001; Owens \& Pasek, 2007; Simmons et al., 2011). Among the best-known occurrences are kyanite quartzites in metamorphosed Palaeozoic volcanic, plutonic and sedimentary rocks of the Piedmont Province of Virginia, which hosts the world's largest kyanite mine. Owens and Pasek (2007) suggested that these rocks originated by severe leaching in a high-sulphidation (advanced argillic) alteration system. Larsson (2001) described a quartz-kyanite rock (with Al-phosphates and rutile) at Hålsjöberg, southern Sweden, as a product of regional amphibolite-facies metamorphism of a high-alumina precursor that originated by previous acid leaching of a (Palaeoproterozoic?) granite. Simmons et al. (2011) inferred that 

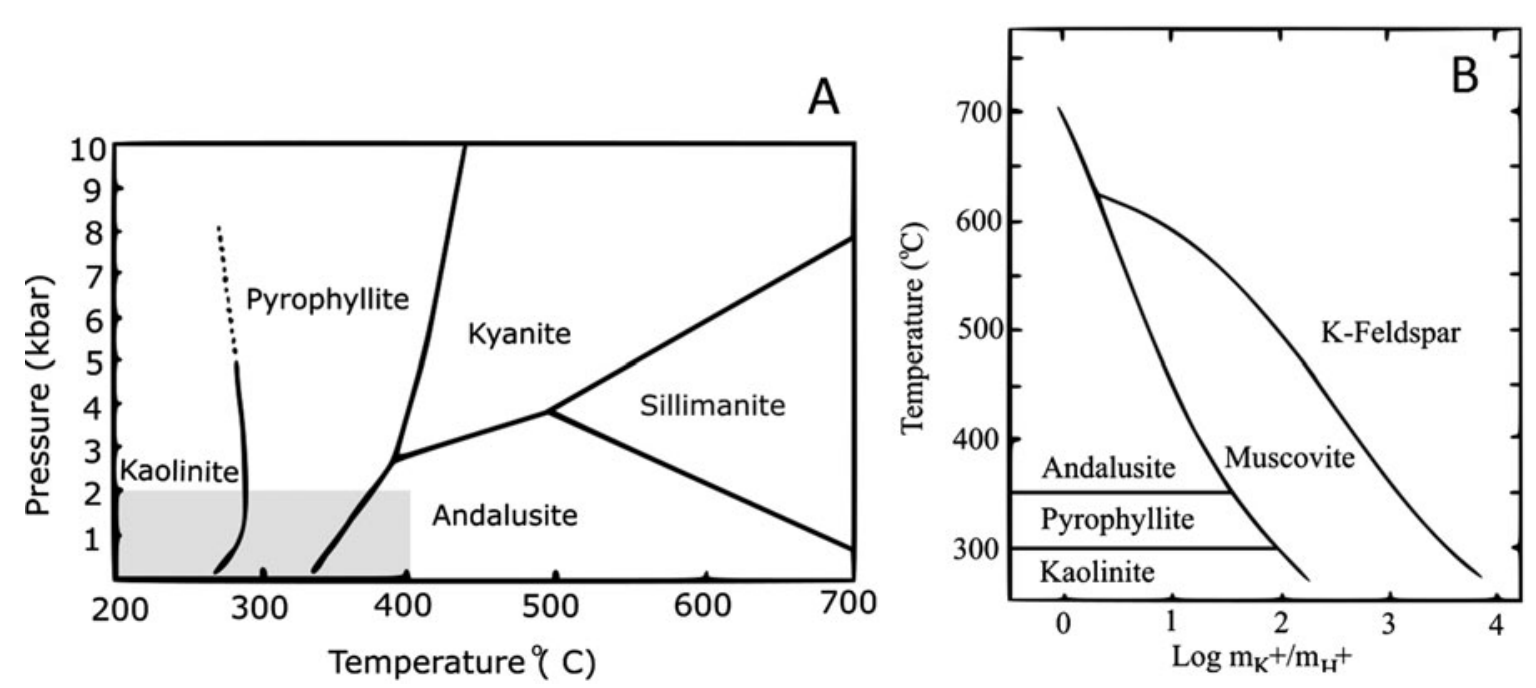

Fig. 9. (A) Stability fields of aluminosilicates expected to occur in rocks affected by hydrolysis, and their metamorphic equivalents. Shaded area represents the approximate $P-T$ interval where hydrolysis and advanced argillic alteration take place. From Larsson (2001) and references therein. (B) Equilibria in the $\mathrm{K}_{2} \mathrm{O}-\mathrm{Al}_{2} \mathrm{O}_{3}-\mathrm{SiO}_{2}-\mathrm{H}_{2} \mathrm{O}$ system with stability fields of aluminosilicates that form during hydrolysis. $P=1 \mathrm{kbar}, \mathrm{m}=$ molarity. Modified from Larsson (2001).

Palaeoproterozoic quartz-kyanite pods in the Tusas Mountains, New Mexico (USA), represent a sheared and metamorphosed fossil hydrothermal system in meta-rhyolite wherein hot acidic fluids produced lenses and zones of clay and other minerals including pyrophyllite, chloritoid and possibly andalusite and staurolite.

Advanced argillic alteration takes place under highly acidic conditions, which leads to a complete destruction of feldspars and $\mathrm{Mg}-\mathrm{Fe}$ silicates and virtually complete leaching of alkalis (Fig. 9). Typical mineral assemblages of advanced argillic alteration at low temperatures include kaolinite/dickite, pyrophyllite, diaspore, alunite-group minerals and barite, with sulphides, topaz and tourmaline frequently as minor phases. At higher alteration temperatures $\left(>300^{\circ} \mathrm{C}\right)$ the assemblages may contain pyrophyllite, andalusite, quartz, topaz and pyrite, possibly accompanied by minor amounts of minerals such as sericite, diaspore, kaolinite, rutile, anhydrite, corundum, zunyite, dumortierite and chloritoid (Pirajno, 2009).

As Figure 10 illustrates, the Bosland quartzites consist almost entirely of $\mathrm{SiO}_{2}\left(72-78 \mathrm{wt} \%\right.$ ) and $\mathrm{Al}_{2} \mathrm{O}_{3}$ (15-21 wt\%). The samples plot close to a line connecting kaolinite (or pyrophyllite) and quartz, indicating that the final assemblage can largely be generated by dehydration during regional metamorphism. The andalusite in the quartzites may well be a relic of the alteration assemblage, since the textures imply that this mineral formed prior to kyanite.

Further support for a hydrothermal alteration history comes from the mineralogical variation in kyanite-bearing quartzites in the Bosland area as described by Ter Meulen (1953). In particular, the sericite- and pyrite-bearing varieties favour such a scenario. Together with differences in modal contents of the Fe-bearing silicates (chloritoid, staurolite), these variations can be attributed to spatial changes in the alteration regime, conceivably superimposed on compositional inhomogeneity of the precursor rocks. The presence of (locally abundant) pyrite and the presumed enrichment of gold are consistent with an advanced argillic alteration environment. The mica-rich schist intercalated between the leached quartzites can be explained by a localised fluid conduit, possibly as a result of differences in permeability.

\section{In search of the protolith}

A first question to be addressed is whether the precursor was an igneous or a sedimentary rock. According to the geological map of Suriname (Bosma et al., 1977), rock lithologies in the direct vicinity of Bosland are primarily metamorphosed sediments and volcanics (Fig. 2A). It is noteworthy that one of these lithologies (unit 34; Bosma et al., 1977) is staurolitegarnet schist, indicating a nearby rock with relatively high iron and aluminum contents. Kroonenberg et al. (2016) refer to this unit as Taffra Schist, a contact-metamorphic rock around Patamaca two-mica granites that locally contains $\mathrm{Al}_{2} \mathrm{SiO}_{5}$ minerals. The compositional differences of the rock suite, its layered nature, and the association of quartzite and intercalated mica schist (Fig. 3) favour a sedimentary sequence, but cannot fully exclude a (partly) volcanic origin. Another option is that chemical differences had a secondary origin and reflect localised interactions with fluids in an originally homogeneous schist, which will be dealt with below.

Further insight into the nature of the precursor can potentially be obtained from a geochemical comparison with known lithologies in the region. Because original ratios of immobile elements remain unchanged, cogenetic samples should plot on 


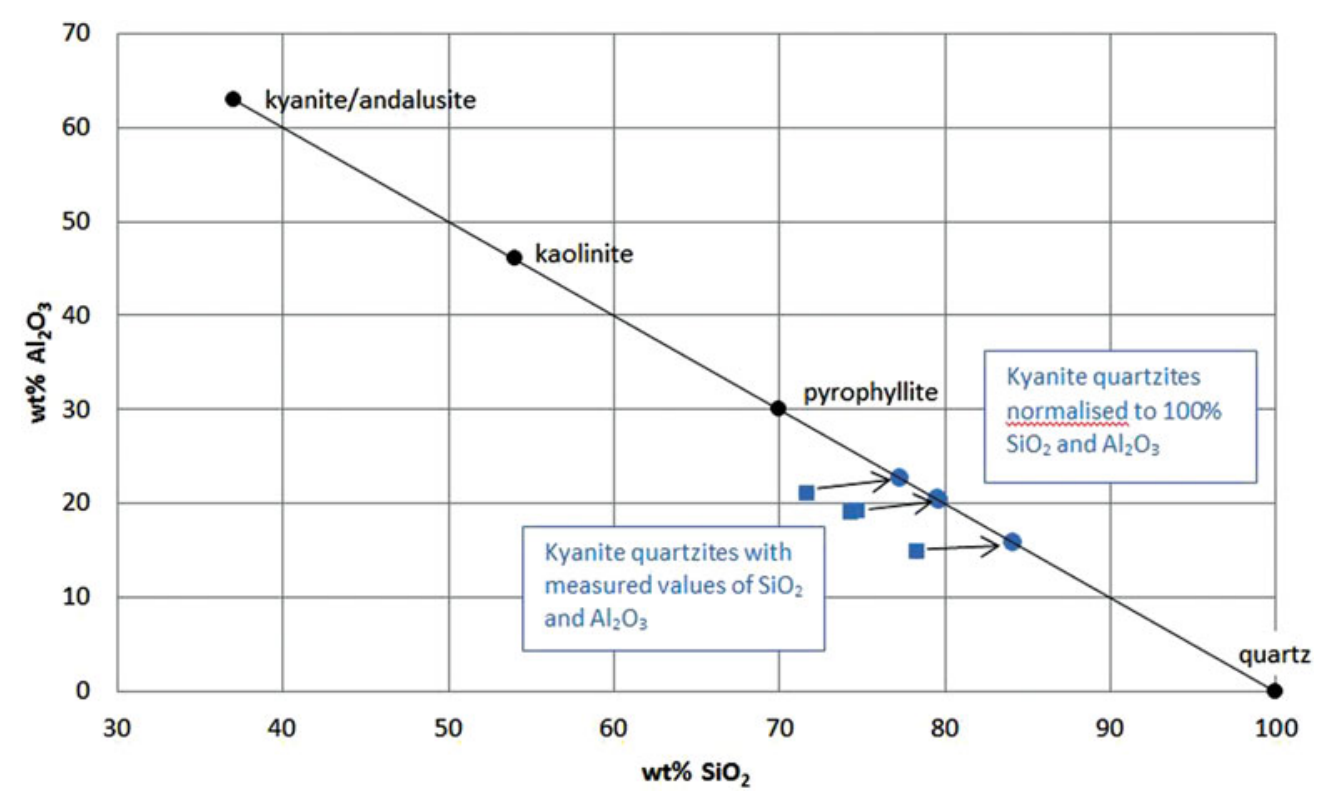

Fig. 10. Diagram illustrating that the main $\mathrm{SiO}_{2}$ - and $\mathrm{Al}_{2} \mathrm{O}_{3}$-bearing metamorphic assemblage in the kyanite quartzites (kyanite-relict andalusite-quartz) is compositionally equivalent to the inferred hydrothermal alteration assemblage kaolinite-pyrophyllite-andalusite-quartz on an $\mathrm{H}_{2} \mathrm{O}$-free basis. Values for kaolinite and pyrophyllite were recalculated volatile-free, and normalised values for the kyanite quartzite samples were recalculated from the measured values to a 100 wt \% total for $\mathrm{Al}_{2} \mathrm{O}_{3}+\mathrm{SiO}_{2}$. Differences from the measured values are small because the sums of all other major oxides and LOI are only 6-8 wt\%.

a linear trend in XY-diagrams, which ideally passes through the precursor and the origin (Barret \& MacLean, 1994). For this purpose, the quartzite samples were plotted together with published major-element concentrations for the main lithologies of the Rosebel area, some of which are mineralised (Daoust et al., 2011), and for lithologies from the Armina Formation outcropping along the Marowijne River (Naipal \& Kroonenberg, 2016). The rocks of both groups belong to the Marowijne Greenstone Belt and thus represent a potential proxy.

In the absence of trace-element data for the Armina Formation along the Marowijne River, the cogenetic plots were created for $\mathrm{Al}_{2} \mathrm{O}_{3}, \mathrm{TiO}_{2}$ and $\mathrm{P}_{2} \mathrm{O}_{5}$ (Naipal \& Kroonenberg, 2016) because these oxides often show immobile behaviour, although there is evidence for mobility of $\mathrm{Al}_{2} \mathrm{O}_{3}$ and $\mathrm{TiO}_{2}$ under specific conditions (Sepahi et al., 2004; Beitter \& Wagner, 2008; Bucholz et al., 2010). For comparison, $\mathrm{Al}_{2} \mathrm{O}_{3}$ contents were also plotted against $\mathrm{SiO}_{2}$. The evaluation for the sedimentary rocks is inconclusive because of their significant scatter (Fig. 11). Compositions of the volcanic rocks are more coherent, especially those of the tuff, andesite and rhyolite samples, but in this case the variation among the quartzites does not allow an unequivocal conclusion to be drawn (Fig. 11). The negative trend in the $\mathrm{SiO}_{2}-\mathrm{Al}_{2} \mathrm{O}_{3}$ diagram for the sedimentary rocks apparently reflects a grain-size effect, with coarser sediments containing more quartz and finer sediments containing more Al-rich clays.

Signatures of immobile trace elements, especially REE and HFSE, appear to be more diagnostic. These elements are considered immobile in hydrous fluids under most conditions, and commonly retain their relative abundances throughout the ge- ological history of a rock. Only in exceptional cases, such as when the fluid is acidic and rich in $\mathrm{Cl}$ and/or $\mathrm{F}$, can the REE and high-field-strength elements (HFSE) become mobile (e.g. Jiang et al., 2005). Figure 12 shows spider diagrams for a set of 'immobile' trace elements in the kyanite quartzites, normalised to average concentrations in each of the Rosebel sedimentary and volcanic rock types of Daoust et al. (2011). A horizontal trend in such a diagram would be indicative of a possible precursor rock.

The first observation is that in all cases $\mathrm{Zr}, \mathrm{Nb}$ and $\mathrm{Ta}$ are more enriched than the other elements. The $\mathrm{Zr}$ enrichment can be explained by the presence of zircon, while $\mathrm{Nb}$ and $\mathrm{Ta}$ are likely hosted in the rutile (Anthony et al., 2005), consistent with a relative enrichment of $\mathrm{TiO}_{2}$ (see below). The shapes of the basalt- and andesite-normalised diagrams strongly deviate from a horizontal trend, which excludes these rock types as precursor. The trends of the rhyolite-, arenite- and mudstone-normalised values are fairly flat but still show minor LREE enrichment. The tuff-normalised compositions yield the best fit, showing the flattest REE part of the pattern and a more modest enrichment of $\mathrm{Zr}, \mathrm{Nb}$ and $\mathrm{Ta}$ than the rhyolite/arenite/mudstone-normalised values. A strong depletion of Th and U suggests that these elements may have been removed during alteration or that their contents in the Rosebel tuff are not representative.

It should be noted that this exercise is not representative for all lithologies present within the Greenstone Belt. The comparison here is based on recent available ICP analysis within a radius of approximately $40 \mathrm{~km}$. As mentioned before, the 

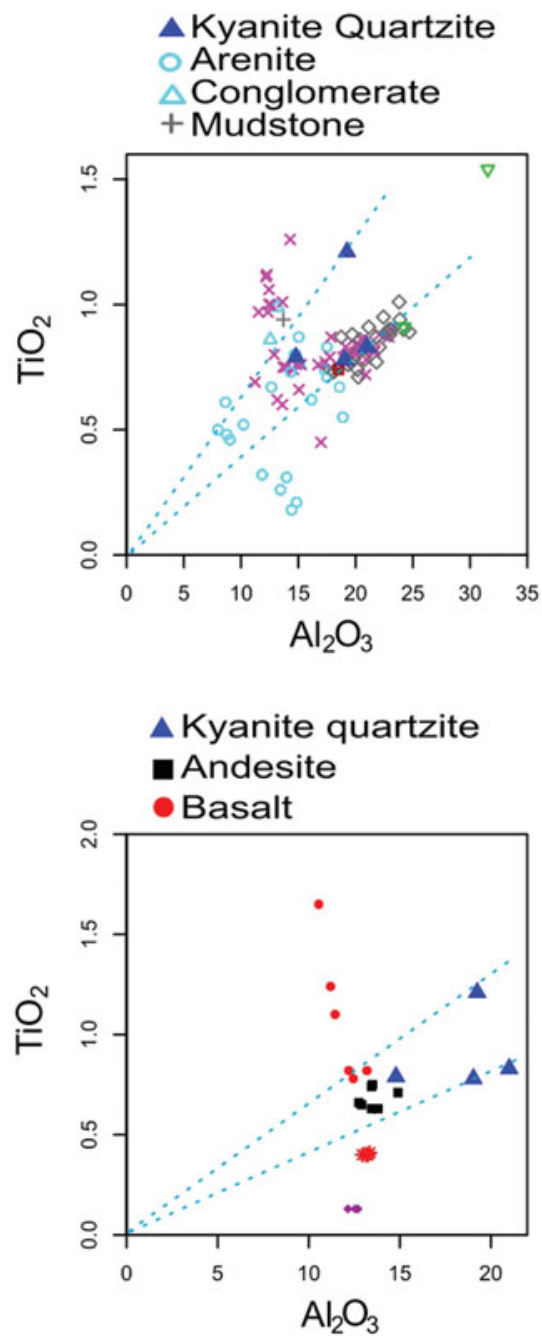

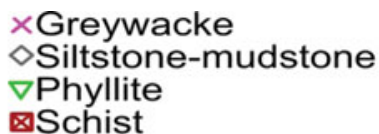
$\otimes$ Schist
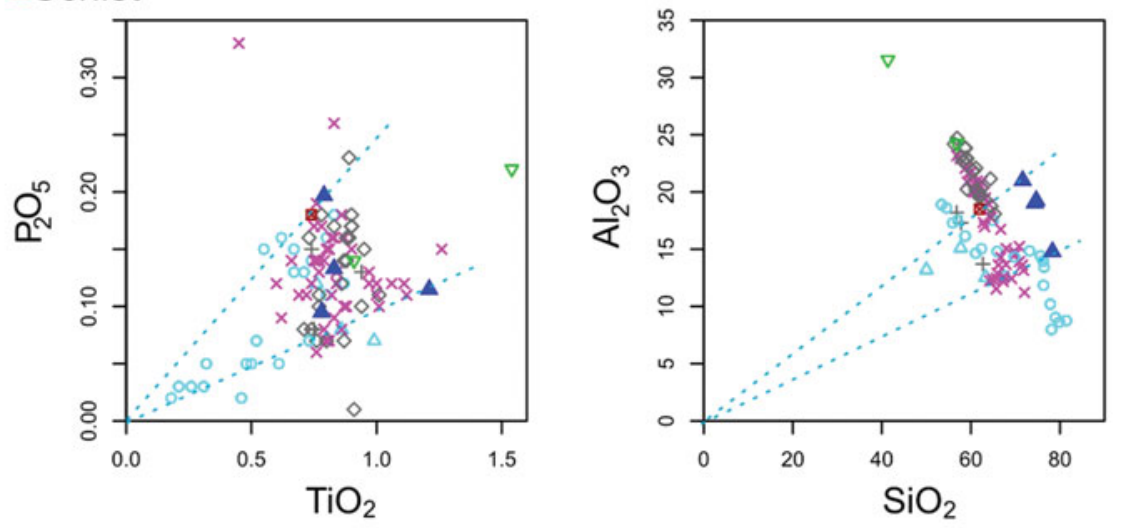

$\rightarrow$ Rhyolite

*Tuff
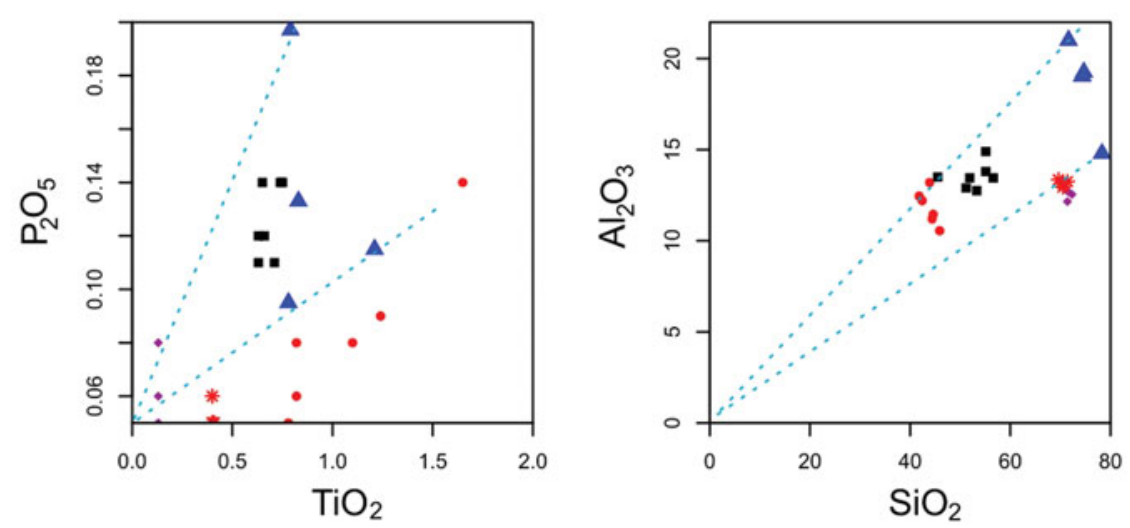

Fig. 11. XY-plots showing immobile major oxides from kyanite quartzites and sedimentary rocks from the Rosebel area and Marowijne River and volcanic rocks from the Rosebel area. Arenite (partially), conglomerate and mudstone are from Daoust et al. (2011). Arenite (partially), greywacke, siltstone-mudstone, phyllite and schist are from Naipal \& Kroonenberg (2016). Volcanic rock compositions from Daoust et al. (2011).

possibility of a mature sedimentary protolith is not ruled out. Due to the metamorphic overprint, little remains of the protolith texture, making chemical composition the best tool for discerning the parent rock. The best fit with the Rosebel tuff indicates that the protolith had a similar composition. It is therefore possible that the protolith could have been the igneous rock or related to the volcanic eruption, the pyroclastic tuff or their weathered, erosional products.

In the $\mathrm{Nb} / \mathrm{Y}-\mathrm{Zr} / \mathrm{TiO}_{2}$ diagram of Winchester \& Floyd (1977), the kyanite quartzites plot within the trachy-andesite field and do not seem to correspond to any of the Rosebel volcanic and sedimentary lithologies (Fig. 13). However, it must be noted that the $\mathrm{Nb}$ and Ti contents in the kyanite quartzites seem to be anomalously high, considering the $\mathrm{Nb}$ peak in the spidergrams (Fig. 12) and the likelihood that both elements are primarily hosted in rutile. If they were mobile and introduced during alteration, the precursor could plot in the rhyodacite/dacite field and closer to the Rosebel tuffs. According to Figure 13, the Rosebel tuff of Daoust et al. (2011) is of rhyodacitic/dacitic composition and thus is better described as an ash-fall tuff. If the precursor rocks were mature arenites, the high $\mathrm{Nb}, \mathrm{Zr}$ and $\mathrm{Ti}$ content could also be caused by heavy mineral concentrations, such as zircon and rutile.

\section{Mass transfer calculations}

Gains and losses of elements during alteration were quantified according to the method of Grant $(1986,2005)$, using

$$
C_{i}^{0}=\frac{M^{0}}{M^{\mathrm{A}}} \times\left(C_{i}^{\mathrm{A}}+\Delta C_{i}\right)
$$

where $C_{i}$ is the concentration of species $i$ and superscripts 0 and $\mathrm{A}$ refer to the original and altered rock, respectively. $M^{0}$ and $M^{\mathrm{A}}$ are the equivalent masses before and after alteration, and $\Delta C_{i}$ is the change in concentration of species $i$. For 

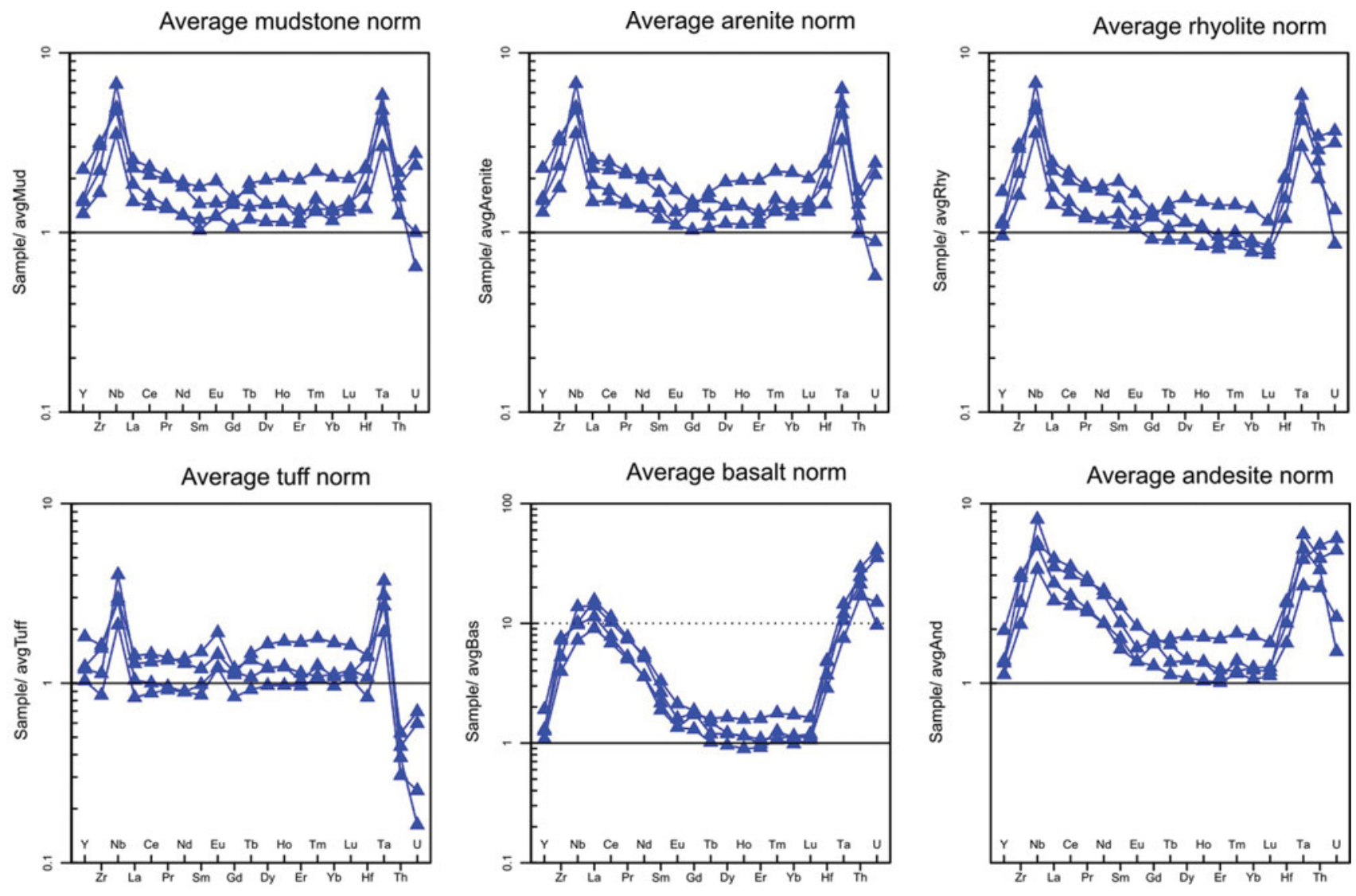

Fig. 12. Spider diagrams of immobile trace elements normalised to averaged concentrations in sediments and volcanics from the Rosebel area calculated from data of Daoust et al. (2011).

immobile elements $\Delta C_{i}=0$, which simplifies Equation (1) into

$$
C_{i}^{0}=\frac{M^{0}}{M^{\mathrm{A}}} \times C_{i}^{\mathrm{A}}
$$

The value of $M^{0} / M^{\mathrm{A}}$, determined from the $C_{i}^{\mathrm{A}} / C_{i}^{0}$ ratios of immobile elements, can be used to calculate the concentration change relative to the original composition for mobile elements according to

$$
\frac{\Delta C_{i}}{C_{i}^{0}}=\left(\frac{M^{\mathrm{A}}}{M^{0}}\right) \times\left(\frac{C_{i}^{\mathrm{A}}}{C_{i}^{0}}\right)-1
$$

Average ash-fall tuff from the Rosebel area (Daoust et al., 2011) was taken as the original rock, and average kyanite quartzite as the altered equivalent. Elements assumed to have been immobile are $\mathrm{REE}, \mathrm{Y}, \mathrm{Zr}$ and $\mathrm{SiO}_{2}$, based on a clustering of their $C_{i}{ }^{\mathrm{A}} / C_{i}{ }^{0}$ ratios. The resulting isocon diagram (Fig. 14) distinguishes these immobile elements from those that were gained (plotting above the isocon line) and those that were lost (below the line).

Figure 15 summarises the element gains and losses in a quantitative way. The alkali and alkaline earth elements are all strongly depleted, showing losses between $85 \%$ and $100 \%$. The reduction of the LOI value $(-67 \%)$ not only reflects primary alteration when hydrous minerals such as kaolinite and pyrophyllite formed, but also includes the effect of their subsequent metamorphic transformation into anhydrous aluminous phases.
The most conspicuous feature is the apparent gain of elements that usually are considered to be immobile: $\mathrm{Ti}, \mathrm{Nb}, \mathrm{Ta}, \mathrm{V}, \mathrm{Al}, \mathrm{Ga}$. The $\geq 100 \%$ enrichment of $\mathrm{Ti}, \mathrm{V}, \mathrm{Nb}$ and $\mathrm{Ta}$ in the quartzites is accommodated by the presence of (locally abundant) rutile as principal host. It implies that HSFE were supplied by fluid that may have extracted these elements from Ti-bearing phases (e.g. biotite, Fe-Ti oxides) in nearby rocks. Experiments have shown that the solubility of Ti is strongly dependent on the composition of the fluid (Rapp et al., 2010 and references therein). In particular, chloride- and fluoride-rich hydrous fluids can dissolve rutile $\left(\mathrm{TiO}_{2}\right)$ up to two orders of magnitude better than pure $\mathrm{H}_{2} \mathrm{O}$. Addition of Al may have been promoted by elevated temperature, pressure or dissolved $\mathrm{SiO}_{2}$ and $\mathrm{NaCl}$, factors that could significantly enhance the solubility of $\mathrm{Al}$ in crustal fluids (Manning, 2006). A final point to note is that the apparently stronger enrichment of $\mathrm{Ga}$ relative to $\mathrm{Al}$ in the kyanite quartzites is a feature that they share with many zones of advanced argillic alteration (Rytuba et al., 2003), although opposite trends have also been documented (0wens \& Pasek, 2007).

\section{Alteration setting}

Advanced argillic alteration is typical for high-sulphur epithermal and porphyry systems, where the responsible acidic fluids 


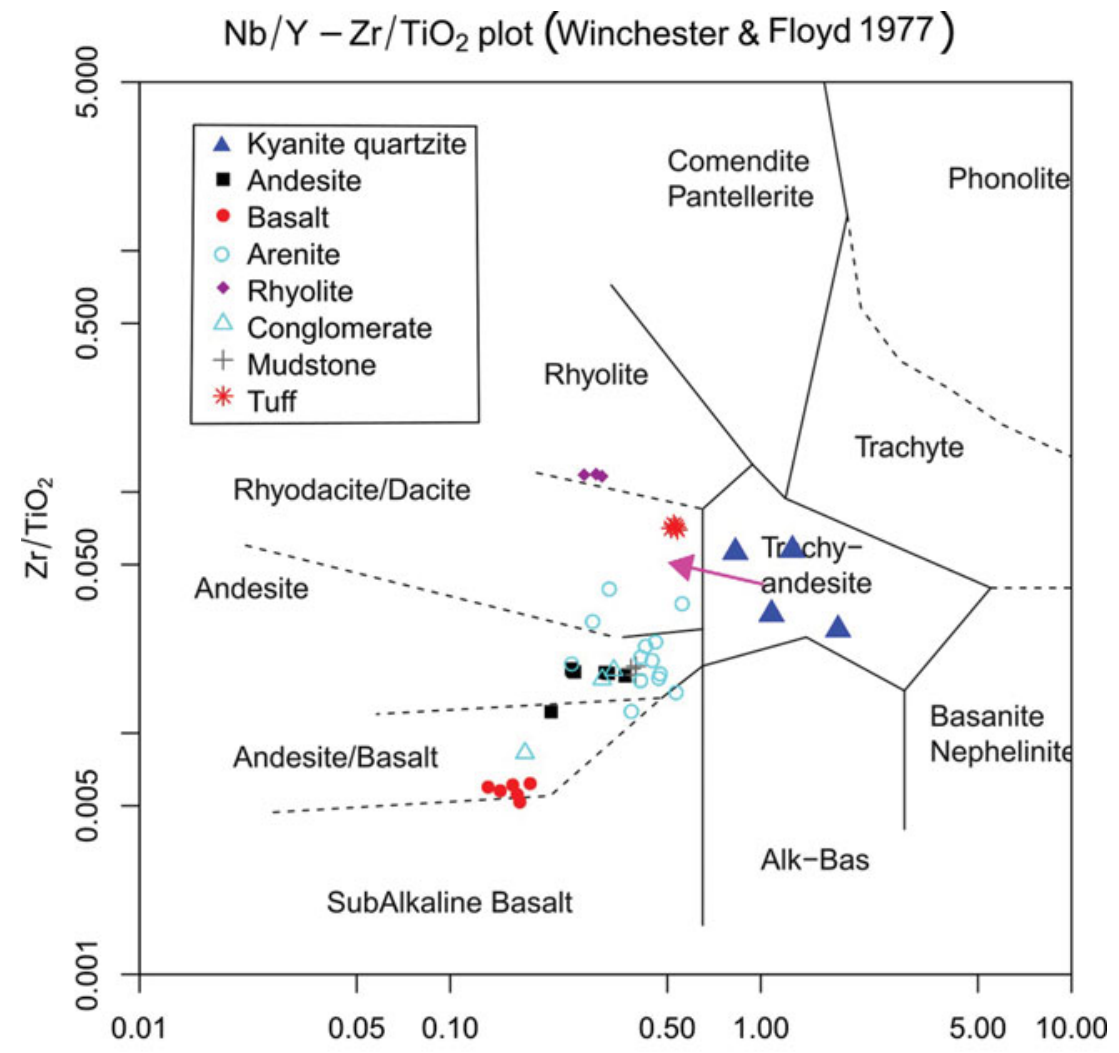

$\mathrm{Nb} / \mathrm{Y}$
Fig. 13. Geochemical classification diagram for volcanic rocks (Winchester \& Floyd, 1977), comparing the signature of the kyanite quartzites with those of volcanic and sedimentary lithologies in the Rosebel area (Daoust et al., 2011). Legend refers to originally assigned rock names. According to this classification, the kyanite quartzites could have had a trachy-andesitic precursor if this was of volcanic origin. It should be noted, however, that the kyanite quartzites may have shifted relative to the precursor since the assumption of element immobility is questionable. are generally associated with a magmatic source. The currently available data are insufficient to constrain the specific setting and origin of fluid that produced alteration in the Bosland area. Some field evidence might be in favour of fairly deep-seated alteration. As shown on the geological map (Fig. 2B), a sizeable body of biotite granite (Unit 23, Bosma et al., 1977) is in close proximity (approximately $5 \mathrm{~km}$ ) to the Dubois Hill. This outcrop lies at Akinto Soela and was described by $0^{\prime}$ Herne (1958). It is conceivable that an acidic hydrothermal fluid could have been derived from this intrusion. Furthermore, as mentioned above, the Dubois Hill seems closely related to large regional structures and known gold deposits (Fig. 2A). The structures can be interpreted based on (1) a dextral shear observed at Pay Caro (Daoust et al., 2011), (2) a shear observed at Sabajo Hill (Patadien, 2013) and (3) the topographic relief as displayed by the digital elevation model (DEM). From this combined evidence the Dubois Hill appears to be situated within a contractional strike-slip duplex, specifically a left stepover of a dextral strike-slip fault. The accompanying localised stress could have been responsible for creating a conduit for strong, localised fluid transport. The kyanite quartzites trend parallel to the eastern and western flank of this strike-slip fault. In this context, it is also of interest to note that fluid migration caused economical gold mineralisation at Sabajo Hill and Pay Caro, which lie directly on the main structure. The Merian gold deposits, situated approximately $17 \mathrm{~km}$ east of the main structure, are characterised by significant veining. These observations also suggest that a fluid may have been associated with the same major dextral strike-slip fault.

Whatever the exact depth of the alteration environment, it is unlikely that the alteration event coincided with peak metamorphic conditions. If this were the case, the alteration would have happened at a relatively high metamorphic grade where kyanite and staurolite are formed. The stability of kyanite requires a pressure of at least $2.8 \mathrm{kbar}$, which is outside the epithermal conditions where advanced argillic alteration usually occurs. Relatively low temperatures and brittle conditions favourable for hydrothermal leaching overlap with $P-T$ conditions where andalusite is stable (Fig. 9). In view of the textural evidence for its formation prior to kyanite, the andalusite in the Bosland quartzites may well belong to the alteration assemblage. Alternatively, it formed during progressive metamorphism before the stability field of kyanite was reached. In contrast, the absence of andalusite in the kyanite veins suggests that the veins did not have the same epithermal history but formed relatively late and close to the peak of metamorphism, probably during late deformation. The formation of kyanite in veins requires mobility of $\mathrm{Al}$ in channelised metamorphic 


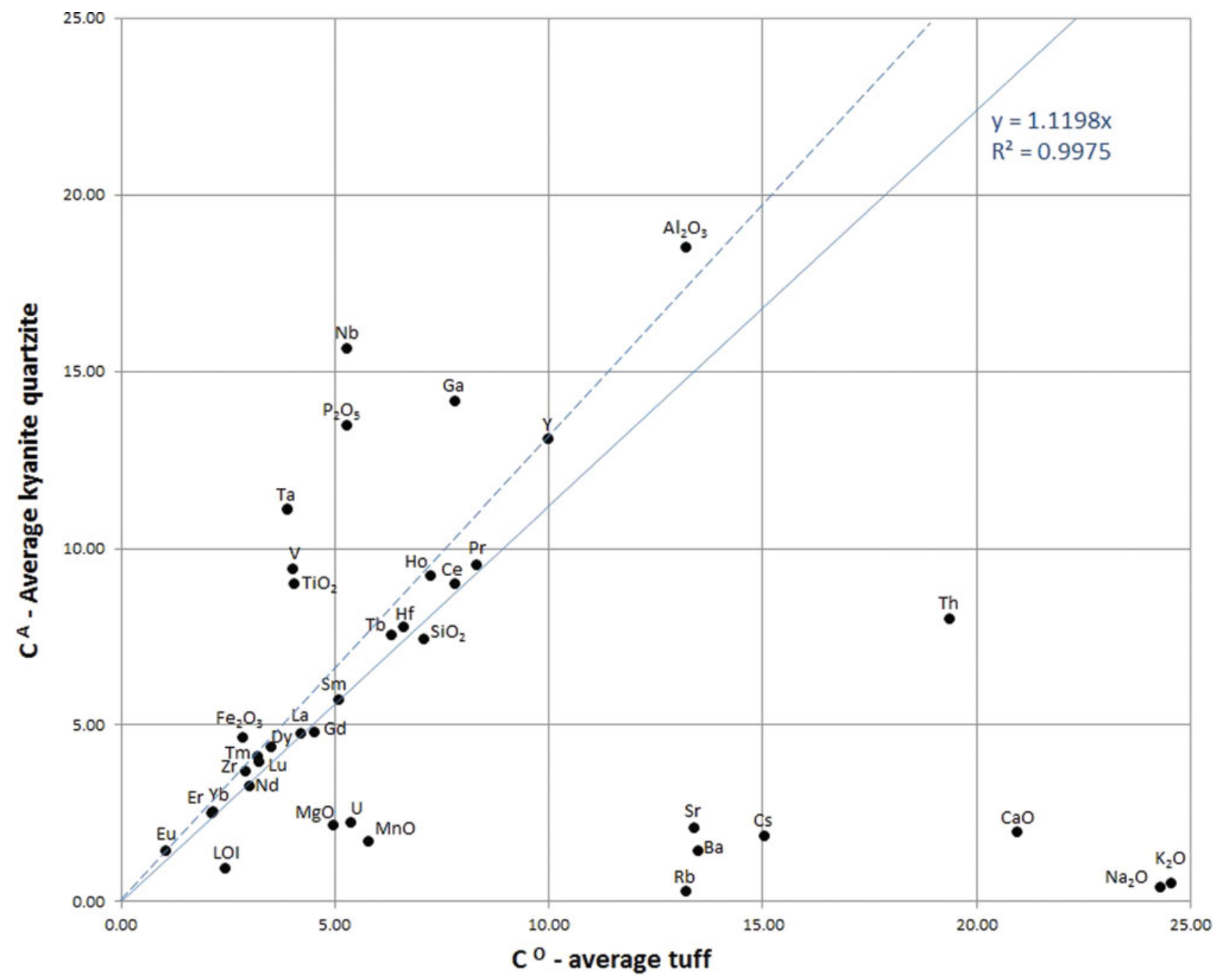

Fig. 14. Diagram illustrating that the main $\mathrm{SiO}_{2}$ - and $\mathrm{Al}_{2} \mathrm{O}_{3}$-bearing metamorphic assemblage in the kyanite quartzites (kyanite-relict andalusite-quartz) is compositionally equivalent to the inferred hydrothermal alteration assemblage kaolinite-pyrophyllite-andalusite-quartz on an $\mathrm{H}_{2} \mathrm{O}-\mathrm{free}$ basis. Values for kaolinite and pyrophyllite were recalculated volatile-free, and normalised values for the kyanite quartzite samples were recalculated from the measured values to a 100 wt \% total for $\mathrm{Al}_{2} \mathrm{O}_{3}+\mathrm{SiO}_{2}$. Differences from the measured values are small because the sums of all other major oxides and LOI are only 6-8 wt\%.

fluids, which is promoted under conditions of relatively highgrade metamorphism and the presence of silica (Sepahi et al., 2004; Bucholz et al., 2010).

\section{Timing of alteration and metamorphism}

It is difficult to assess whether a significant time gap separated the alteration event from the moment when metamorphism reached its maximum. Alteration under epithermal conditions could have been followed by a period of cooling before regional metamorphism at increasing pressure set in. Such a temperature path is conceivable for a scenario wherein the alteration of the volcanic material was closely associated in space and time with magmatism that was contemporaneous with volcanic activity that produced the erupted products at the surface. Al- ternatively, the alteration took place much later when tectonics had brought the volcanic precursor at deeper crustal levels. In this case the alteration fluid could have been largely derived from an intruded magma body that was emplaced during the earlier stages of regional mountain building. In such a scenario it is conceivable that the Patamacca Granite, which intruded at $2.06 \mathrm{Ga}$ (Kroonenberg et al., 2016), is related to the metamorphism at Bosland. If the Bosland metamorphism is associated with the regional dextral strike-slip faults (Fig. 7), the age might be similar to that of the Neorhyacian D2b deformation phase at 2.07-2.06 Ga (Delor et al., 2003; Daoust et al., 2011). The style of deformation fits with WNW-ESE dextral strike-slip movements identified in northern French Guiana that were accompanied by intrusion of granitic magma (Delor et al., 2003; Daoust et al., 2011). Based on textural evidence the alteration 


\section{Gains/losses from average tuff to average kyanite quartzite}

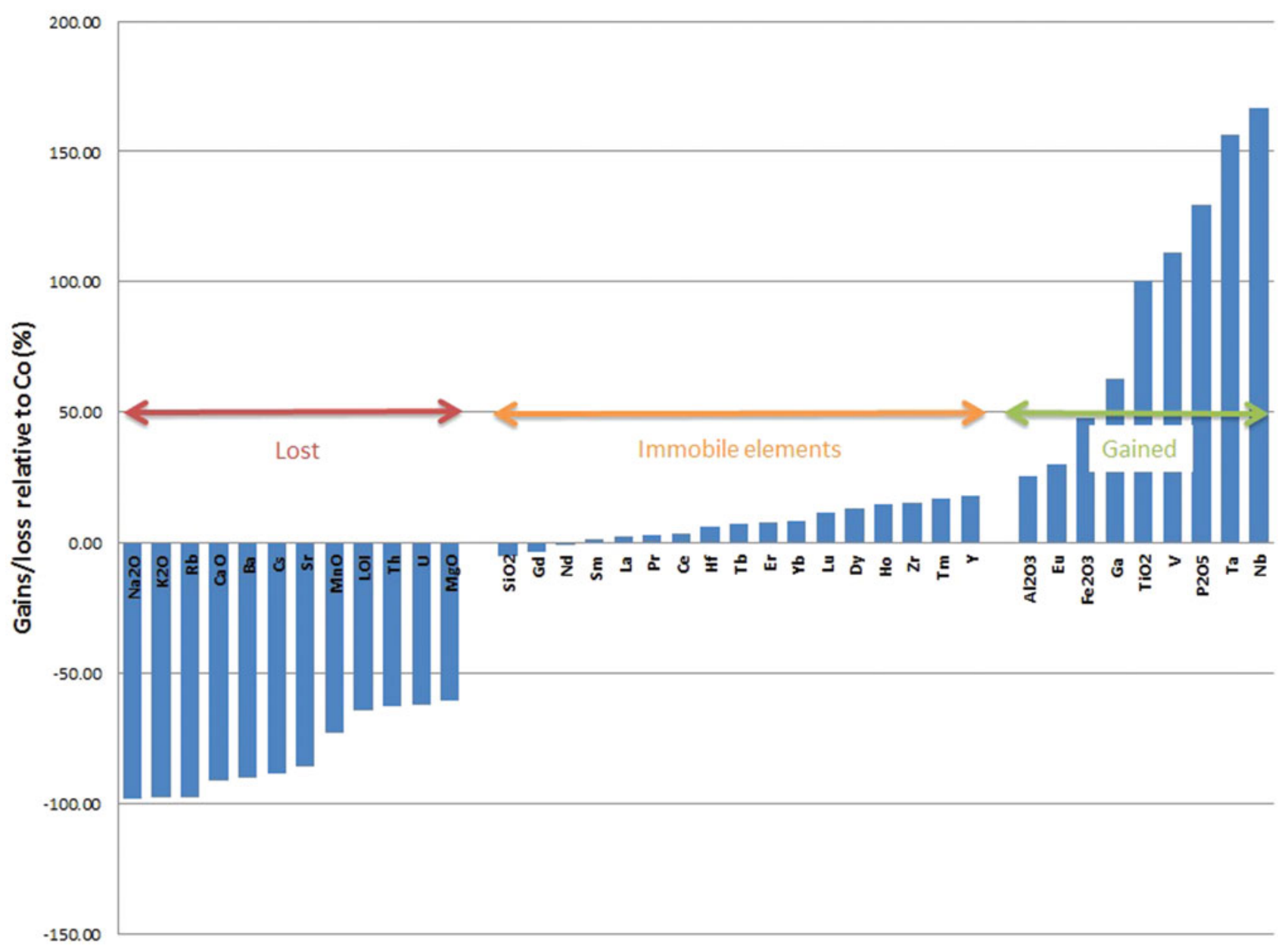

Fig. 15. Gains and losses for the alteration from ash-fall tuff (Rosebel area) to kyanite quartzite (Dubois Hill), based on the isocon method of Grant (1986, 2005) and composition averages from Daoust et al. (2011) and this work.

at Bosland must pre-date the metamorphism. The cross-cutting quartz and kyanite quartz veins indicate a post-metamorphic fluid interaction that remobilised the $\mathrm{Al}$.

\section{Pressure-temperature evolution}

Given this uncertainty in the timing of events, two different $P-T$ paths for the Bosland kyanite quartzites can be hypothesised from the mineral assemblage, textural relationships and the calculated pseudosection. Whereas start and end points seem relatively fixed, the middle part of the trajectory is ambiguous. The path must have begun in $P-T$ conditions under which advanced argillic alteration commonly takes place (orange dashed rectangle in Fig. 16). The exact starting conditions are difficult to determine because of the metamorphic overprint but may well have been at the high-temperature end, i.e. within the andalusite-phengite-chloritoid stability field. If andalusite was a product of metamorphism and did not belong to the alteration assemblage, the alteration could have taken place at lower temperatures, e.g. in one of the fields where kaolinite is stable.

The onset of regional metamorphism was accompanied by increasing pressure resulting in a steepening $P-T$ trajectory. Because of the coexistence of staurolite and chloritoid in the rocks, it is reasonable to assume that the $P-T$ path ended close to or inside the narrow field where both minerals are stable in the presence of kyanite (field 10 in Fig. 16). Textural relationships between staurolite and chloritoid are inconclusive for constraining the exact end point of progressive metamorphism, but it must have reached its maximum in the kyanite stability field since no sillimanite was observed.

Figure 16 shows two possible scenarios for the pressuretemperature evolution. In the first scenario, alteration occurred at very low $P$ and $T$ possibly reaching the andalusite field, and was followed by cooling, still at low $P$, before regional metamorphism commenced and both $T$ and $P$ increased until the end point was reached. In the second scenario, alteration occurred shortly before metamorphism, took place at somewhat 


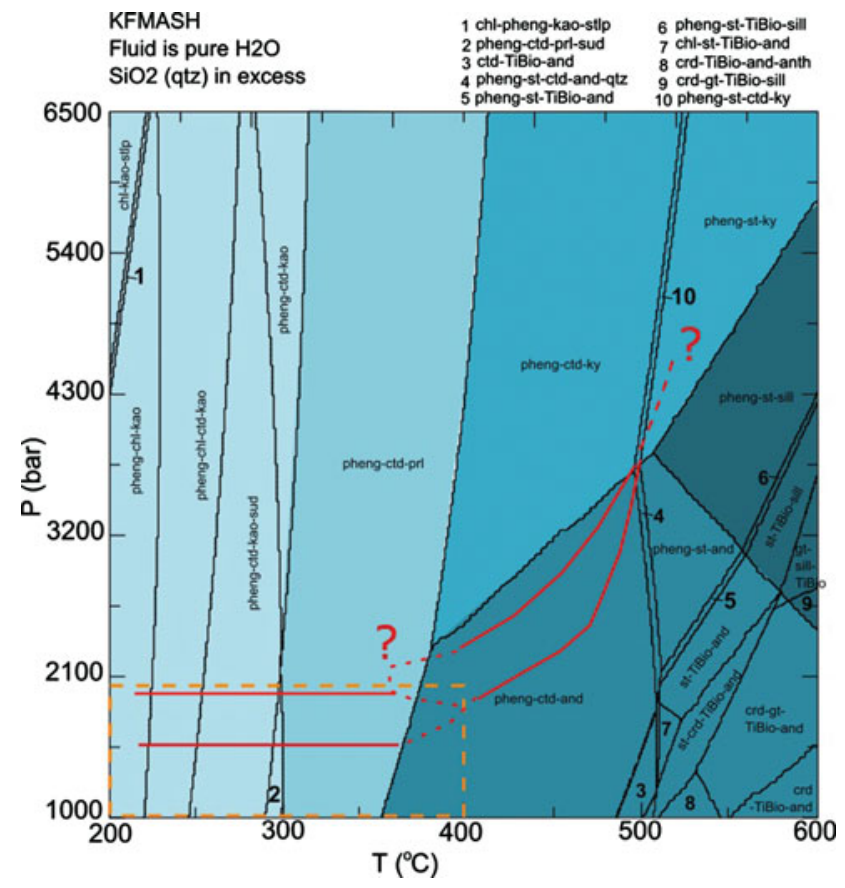

Fig. 16. Hypothetical P-T path for the kyanite quartzites. The orange dashed area represents $P-T$ conditions at which advanced argillic alteration commonly takes place (Larsson, 2001). There is uncertainty about the last part of the path because of the unclear age relationship of chloritoid and staurolite. Note that in this scenario a possible period of cooling between alteration and the onset of metamorphism is ignored.

higher pressures, and was taken over by metamorphism that ultimately reached the upper greenschist - lower amphibolite facies.

\section{Implications for mineral exploration}

The presence of a metamorphosed alteration system at Bosland may have important implications for strategies of mineral exploration in the greenstone belt of Suriname because of (1) the local association with gold mineralisation, (2) links between epithermal alteration and gold deposition (e.g. Sillitoe and Hedenquist, 2003) and (3) the setting of Bosland close to a regional transform structure connecting the major gold deposits of Rosebel and Merian (Fig. 2A). Although most of the gold deposits of the Guiana Shield, including those in Suriname, are generally regarded as orogenic (Voicu et al., 2001; Daoust et al., 2011), the Bosland setting supports the likelihood that other mineralisation styles were also effective. This is highlighted by the Brazilian Tapajós gold province, where Juliani et al. (2005) documented the first evidence for highsulphidation gold mineralisation in the Amazonian Craton. The mineralised systems are hosted in Palaeoproterozoic, weakly deformed and unmetamorphosed volcanic sequences related to large caldera complexes. Strong advanced argillic alteration that affected hydrothermal breccias is represented by (natro-) alunite, pyrophyllite, andalusite, quartz, rutile, diaspore, aluminium phosphate-sulfate minerals, kaolinite, and pyrite, an assemblage that might be close to the precursor of the Bosland kyanite quartzites.

Products of Precambrian alteration are usually metamorphosed, often to a medium or high grade, which makes it difficult to recognise the original genetic signature of the mineralised lithology. A significant number of gold deposits in regional metamorphic settings world-wide have been identified where $\mathrm{Al}_{2} \mathrm{SiO}_{5}$-rich metamorphic assemblages represent original lithologies that underwent argillic hydrothermal alteration. For example, the Neoproterozoic Chapada $\mathrm{Cu}-\mathrm{Au}$ deposit in Brazil is interpreted to have formed as a porphyry-type mineralisation that was overprinted by a shear-zone hosted mineralisation (Oliveira et al., 2016). Kyanite, as well as sillimanite, staurolite and garnet, formed during regional amphibolite-facies metamorphism of quartz-kaolinite (or pyrophyllite) rich products of advanced argillic hydrothermal alteration. Garde et al. (2012) documented the preservation of Mesoarchaean epithermal gold mineralisation in volcano-sedimentary rocks of a relict andesitic arc in the North Atlantic craton of West Greenland, which were metamorphosed at upper amphibolite-facies grade and contain almost pure quartz-sillimanite rocks. The LaRonde Penna worldclass Volcanogenic Massive Sulphide (VMS) deposit in the Canadian Abitibi greenstone belt, which currently shows greenschist to lower amphibolite metamorphic assemblages, is marked by aluminous alteration zones interpreted to be the metamorphic equivalent of an advanced argillic alteration (Dubé et al., 2007). The Palaeoproterozoic Enåsen gold deposit in the Baltic Shield of central Sweden, hosted in quartz-sillimanite supracrustal rocks metamorphosed under upper amphibolite to granulite facies conditions, is thought to be an analogue of recent epithermal $\mathrm{Au}$ deposits associated with acid-sulphate alteration (Hallberg, 1994).

These examples serve to emphasise that the inferred petrogenetic history of the Bosland kyanite quartzites signals the potential of gold mineralisation events prior to peak metamorphism in the Surinamese greenstone belt. Further detailed work is required to explore the extent and nature of ancient hydrothermal alteration processes and to establish whether they are associated with epithermal, porphyry, VMS or other mineralisation styles.

\section{Conclusions}

The origin of kyanite quartzites at Bosland can be explained by a sequence of intense rock alteration, followed by regional metamorphism during the Trans-Amazonian orogeny. From petrological, geochemical and field evidence a model is envisaged wherein strong interaction between acidic fluids and a rhyolithic-dacitic tuff, involving extensive leaching of alkalis and alkaline earth elements, produced a highly altered rock, 
which was subsequently metamorphosed into the present mineral assemblage.

Based on pseudosection modelling and textural relationships, the $P-T$ history of the kyanite quartzites is inferred to have started with shallow ( $<2 \mathrm{kbar}$ ) hydrothermal alteration of the original volcanic rock, possibly in the andalusite stability field $\left(T>350^{\circ} \mathrm{C}\right)$, and to have ended in the kyanite-staurolite stability field $\left(P>4 \mathrm{kbar}\right.$ and $\left.T=500-650^{\circ} \mathrm{C}\right)$. It is uncertain whether hydrothermal alteration was followed by a significant interval of cooling before peak metamorphism was reached.

The results of this research underscore the likelihood that alteration events from before the peak of Trans-Amazonian metamorphism are preserved in the rock record, and fuel the expectation of more differentiation in setting and timing of gold mineralisation in the greenstone belt of Suriname.

\section{References}

Anthony, J.W., Bideaux, R.a., Bladh, K.W. \& Nichols, M.C. 2005. Rutile. In: Handbook of Mineralogy 10. Mineral Data Publishing (Tucon, AZ): 187-190.

Bárdossy, G. \& Aleva, G.J. 1990. Lateritic bauxites. Developments in Economic Geology 27. Elsevier (Amsterdam): $624 \mathrm{pp}$.

Barret, T.J. \& MacLean, W.H. 1994. Chemostratigraphy and hydrothermal alteration in exploration for VHMS deposits in greenstones and younger volcanic rocks. In: Lentz, D.R. (ed.): Alteration and alteration processes associated with ore-forming systems. Geological Association of Canada, Short Course Notes 11. Geological Association of Canada (St John's, Nfld): 433-467.

Beitter, T. \& Wagner, T. 2008. Formation of kyanite - quartz veins of the Alpe Sponda, Central Alps, Switzerland: implications for Al transport during regional metamorphism. Contributions to Mineralogy and Petrology 156: 689707.

Bol, L.C.G.M., Maijer, C. \& Jansen, J.B.H. 1989. Premetamorphic lateritisation in Proterozoic metabasites of Rogaland, SW Norway. Contributions to Mineralogy and Petrology 103: 306-316.

Bosma, W., Kroonenberg, S.B., Van Lissa, R.V., Maas, K. \& De Roever, E.W.F. 1977. Geological Map of Suriname. Geological and Mining Service of Surinam (Parambiro).

Bucholz, C.E., Ague, J.J. \& Haven, N. 2010. Fluid flow and Al transport during quartz-kyanite vein formation, Unst, Shetland Islands, Scotland. Journal of Metamorphic Geology 28: 19-39.

Daoust, C., Voicu, G., Brisson, H. \& Gauthier, M. 2011. Geological setting of the Paleoproterozoic Rosebel gold district, Guiana Shield, Suriname. Journal of South American Earth Sciences 32(3): 222-245.

De Haan, W. 1953. Korte mededeling betreffende een kyanietafzetting in Suriname. Geologie en Mijnbouw 15: 179-182.

De Vletter, D. 1984. Synthesis of the Precambrium of Suriname and review of some outstanding problems. In: Contributions to the Geology of Suriname 8. Ministry of Natural Resources and Energy - Surinam Government Geological and Mining Service (Paramaribo): 11-30.

De Wall, H., Pandit, M. K., \& Chauhan, N. K. 2012. Paleosol occurrences along the Archean - Proterozoic contact in the Aravalli. Precambrian Research 216219: 120-131.
Delor, C., Lafon, J., Lahond, D., Rossi, P., Cocherie, A., Guerrot, C. \& Potrel, A. 2003. The Bakhuis ultrahigh-temperature granulite belt (Suriname ): II. Implications for late Transamazonian crustal stretching in a revised Guiana Shield framework. Géologie de la France 2003 (2-4): 207-230.

Doyle, M.G., Fletcher, I.R., Foster, J., Spencer, E.T. \& Wilkinson, J.J. 2004. Possible submarine advanced argillic alteration at the Basin Lake Prospect, Western Tasmania, Australia Nicholas. Economic Geology 99: 987-1002.

Du Bois. 1901. Geologisch-Bergmannische Skizzen aus Surinam. Freiberg in Sachsen.

Dubé, B., Mercier-Langevin, P., Hannington, M., Lafrance, B., Gosselin, G. \& Gosselin, P. 2007. The LaRonde Penna world-class Au-rich volcanogenic massive sulfide deposit, Abitibi, Québec: mineralogy and geochemistry of alteration and implications for genesis and exploration. Economic Geology 102: 633-666.

Garde, A.A., Whitehouse, M. \& Christensen, R. 2012. Mesoarchean epithermal gold mineralization preserved at upper amphibolite-facies grade, Qussuk, Southern West Greenland. Economic Geology 107: 881-908.

Golani, P.R. 1989. Sillimanite-corundum deposits of Sonapahar, Meghalaya, India: a metamorphosed Precambrian paleosol. Precambrian Research 43: 175-189.

Grant, J.A. 1986. The isocon diagram - a simple solution to Gresens' equation for metasomatic alteration. Economic Geology 81: 1976-1982.

Grant, J. A. 2005. Isocon analysis: a brief review of the method and applications. Physics and Chemistry of the Earth 30: 997-1004.

Hallberg, A. 1994. The Enasen gold deposit, central Sweden. Mineralium Deposita 162: 150-162.

Jiang, S.-Y., Wang, R.-C., Xu, X.-S., \& Zhao, K.-D. 2005. Mobility of high field strength elements (HFSE) in magmatic-, metamorphic-, and submarinehydrothermal systems. Physics and Chemistry of the Earth 30: 10201029.

Juliani, C., Rye, R.O., Nunes, C.M.D., Snee, L.W., Corrêa Silva, R.H., Monteiro, L.V.S., .. Neto, A.A. 2005. Paleoproterozoic high-sulfidation mineralization in the Tapajós gold province, Amazonian Craton, Brazil: geology, mineralogy, alunite argon age, and stable-isotope constraints. Chemical Geology 215 (14): 95-125.

Kartoredjo, H. 1983. Past exploration works for kyanite in the Bosland area. Anton de Kom University of Suriname (Paramaribo).

Kroonenberg, S.B., de Roever, E.W.F., Fraga, L.M., Reis, N.J., Faraco, T., Lafon, J.-M., .. Wong, T.E. 2016. Paleoproterozoic evolution of the Guiana Shield in Suriname: a revised model. Netherlands Journal of Geosciences (May): 1-32. doi: 10.1017/njg.2016.10.

Larsson, D. 2001. Transition of granite to quartz-kyanite rock at Hålsjöberg , southern Sweden: consequence of acid leaching and later metamorphism. Gff 123 (4): 237-246.

Manning, C.E. 2006. Mobilizing aluminum in crustal and mantle fluids. Journal of Geochemical Exploration 89 (1-3): 251-253.

Müller, A., Ihlen, P.M., Wanvik, J.E. \& Flem, B. 2007. High-purity quartz mineralisation in kyanite quartzites, Norway. Mineralium Deposita 42: 523535.

Naipal, R. \& Kroonenberg, S.B. 2016. Provenance signals in metaturbidites of the Paleoproterozoic greenstone belt of the Guiana Shield in Suriname. Netherlands Journal of Geosciences (May): 1-23. doi: 10.1017/njg.2016.9

O'Herne, L. 1958. Blad Berg en Dal. C7-22. Geologische Kaart 1:100.000. Geologische en Mijnbouwkundige Dienst Suriname (Paramaribo): 19 pp. 
Oliveira, C.G. de, Oliveira, F.B. de, Giustina, M.E.S. Della, Marques, G.C., Dantas, E.L., Pimentel, M.M. \& Buhn, B.M. 2016. The Chapada $\mathrm{Cu}-\mathrm{Au}$ deposit, Mara Rosa magmatic arc, Central Brazil: constraints on the metallogenesis of a Neoproterozoic large porphyry-type deposit. Ore Geology Reviews 72: $1-21$.

Owens, B.E., \& Pasek, M.A. 2007. Kyanite quartzites in the Piedmont Province of Virginia: evidence for a possible high-sulfidation system. Economic Geology 102(3): 495-509.

Patadien, R.S. 2013. A study of the lithofacies and structural features at the Sabajo Hills Area, District of Para. Anton de Kom University of Suriname (Paramaribo).

Pirajno, F. 2009. Hydrothermal processes and mineral systems. Springer (New York): $1250 \mathrm{pp}$.

Price, J.R., \& Velbel, M.A. 2003. Chemical weathering indices aplied to weathering profiles developed on heterogenous felsic metamorphic parent rocks. Chemical Geology 202: 397-416.

Reimer, T.O. 1986. Alumina-rich rocks from the early Precambrian of the Kaapvaal Craton as indicators of paleosols and as products of other decompositional reactions. Precambrian Research 32: 155-179.

Ririe, G.T. 1990. A comparison of alteration assemblages associated with archean gold deposits in Western Australia with Paleozoic gold deposits in the southeast United States. Canadian Journal of Earth Sciences 27: 1560-1576.

Rytuba, J.J., John, D.A., Foster, A., Ludington, S.D. \& Kotlyar, B. 2003. Hydrothermal enrichment of gallium in zones of advanced argillic alteration - examples from the Paradise Peak and McDermitt Ore Deposits, Nevada. In: Bliss, J.D., Moyle, P.R. \& Long, K.R. (eds): Contributions to Industrial-Minerals Research (US Geological Survey Bulletin 20): chapter C.

Salzgitter Industriebau Gesellschaft $\mathbf{M B H}$. 1966. Preliminary study on the utilization of kyanite and sand in Surinam, Part I. Salzgitter Drütte: 65pp.
Sepahi, A.A., Whitney, D.L. \& Baharifar, A.A. 2004. Petrogenesis of andalusite - kyanite - sillimanite veins and host rocks, Sanandaj-Sirjan metamorphic belt, Hamadan, Iran. Journal of Metamorphic Geology 22: 119-134.

Sillitoe, R.H. \& Hedenquist, J.W., 2003. Linkages between volcanotectonic settings, ore-fluid compositions, and epithermal precious metal deposits. Society of Economic Geologists Special Publication 10: 315-343.

Simmons, M.C., Karlstrom, K.E., Williams, M.W. \& Larson, T.E. 2011. Quartzkyanite pods in the Tusas Mountains, northern New Mexico: a sheared and metamorphosed fossil hydrothermal system in the Vadito Group metarhyolite. In: New Mexico Geological Society 62nd annual Fall Field Conference guidebook. New Mexico Geological Society (Socorro, NM): 359-378.

Sun, S.S. \& McDonough, W.F. 1989. Chemical and isotopic systematics of oceanic basalts: implications for mantle composition and processes. In: Saunders, D. \& Norry, M.J. (eds): Magmatism in the ocean basins. Geological Society of London, Special Publication 42: 313-345.

Taylor, S.R. \& McLennan, S.M. 1985. The Continental Crust; its composition and evolution; an examination of the geochemical record preserved in sedimentary rocks. Blackwell, (0xford).

Ter Meulen, I.A.C. 1953. Beschrijving van Enkele Gesteenten van Boschland, Suriname. Overdruk uit Geologie en Mijnbouw, Nw. Serie, 15: 183-193

Voicu, G. \& Bardoux, M. 2002. Geochemical behavior under tropical weathering of the Barama-Mazaruni greenstone belt at 0mai gold mine, Guiana Shield. Applied Geochemistry 17: 321-336.

Voicu, G., Bardoux, M. \& Stevenson, R. 2001. Lithostratigraphy, geochronology and gold metallogeny in the northern Guiana Shield, South America: a review. Ore Geology Reviews 18: 211-236.

Winchester, J.A. \& Floyd, P.A. 1977. Geochemical discrimination of different magma series and their differentiation products using immobile elements. Chemical Geology 20: 325-343. 